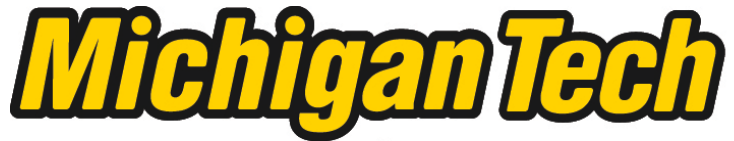 \\ Michigan Technological University Create the Future Digital Commons @ Michigan Tech
}

\section{Effect of an inquiry-based curriculum and experiential education of middle school students' attitude in science}

Angela Rae Teubert

Michigan Technological University

Follow this and additional works at: https://digitalcommons.mtu.edu/etds

Part of the Science and Mathematics Education Commons

Copyright 2006 Angela Rae Teubert

\section{Recommended Citation}

Teubert, Angela Rae, "Effect of an inquiry-based curriculum and experiential education of middle school students' attitude in science", Master's report, Michigan Technological University, 2006.

https://doi.org/10.37099/mtu.dc.etds/527

Follow this and additional works at: https://digitalcommons.mtu.edu/etds

8 Part of the Science and Mathematics Education Commons 


\title{
The Effect of an Inquiry-Based Curriculum and Experiential Education on Middle School Students' Attitude in Science
}

By

Angela Rae Teubert

\begin{abstract}
A Research Report
Submitted in partial fulfillment of the requirements

for the degree of

MASTER OF APPLIED SCIENCE EDUCATION
\end{abstract}

\author{
Michigan Technological University \\ 2006
}

Copyright @ Angela R. Teubert 2006 
(This page deliberately blank) 
This research report, "The Effect of an Inquiry-Based Curriculum and Experiential Education on Middle School Students' Attitude in Science," is hereby approved in partial fulfillment of the requirements for the degree of MASTER OF APPLIED SCIENCE EDUCATION.

DEPARTMENT or PROGRAM:

Department of Education

Signatures:

Thesis Advisor

Typewritten Name William L. Yarroch

Department Chair

Typewritten Name Brad Baltensperger

Date September 8, 2006 
(This page deliberately blank) 


\section{Acknowledgements}

I would first like to thank all of the students at Mountain Ridge Middle School who were willing to take part in this study. I realize it was the end of the school year and any extra work seemed like an overwhelming task. I also give my deepest gratitude to Caron Kosters who was willing to prepare, write and teach lesson plans directly related to this research study. The time and hard work you put has helped me get a Masters!

Enormous thanks to Kathleen Shiverdecker for teaching me what "active voice" is and for sharing your incredible talents in writing and editing. I appreciated the time you spent walking me through the literature review and all the time you spent on editing parts of this thesis. Thanks to Tammi Holt for also helping me with editing, I appreciate the time and patience you spent with me instead of your family.

This paper would not have been written if it had not been for the Challenger Learning Center. Thank you to the administration and staff of the Challenger Learning Center. I am honored to have been able to work with your crew and use the remarkable facilities that you offer to our community.

Thank you to my family for listening to me complain as I worked on this paper throughout the spring and summer. Nathan I appreciate your knowledge of computers, especially in Word. I am sorry I was unable to pay you for your help but thanks for teaching me more about Word than I will probably ever need to know.

Finally I would like to thank Dr. Yarroch for guiding me in this complex endeavor. I appreciate the time you took out of your summer to guide me though each chapter of this thesis. You knowledge of current research in education was very helpful for this the final paper. I am grateful and thankful for the knowledge, patience, thoroughness, and computer expertise. 
(This page deliberately blank) 


\section{Table of Contents}

ACKNOWLEDGEMENTS

TABLE OF CONTENTS

LIST OF TABLES AND FIGURES

CHAPTER 1 - STATEMENT OF TOPIC AND ITS IMPORTANCE

1

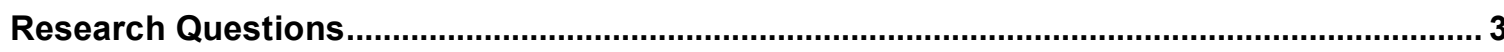

Variable Definition .................................................................................................. 3

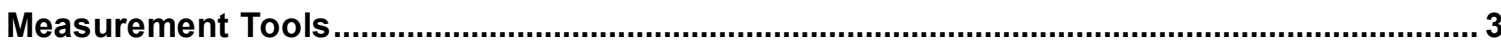

Hypothesized Results ................................................................................................................... 4

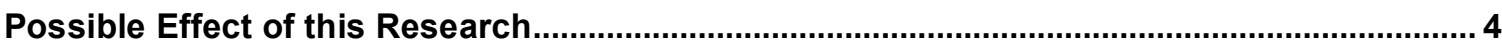

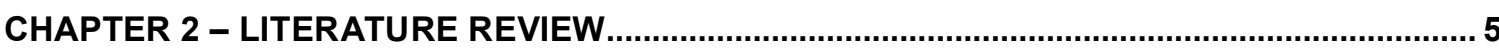

Students' Attitude Towards Science .................................................................................... 5

Inquiry vs. Traditional Curriculum..................................................................................... 7

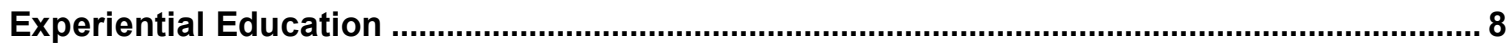

CHAPTER 3 - PROCEDURES ....................................................................................... 13

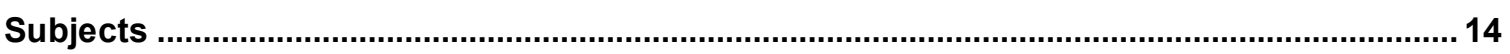

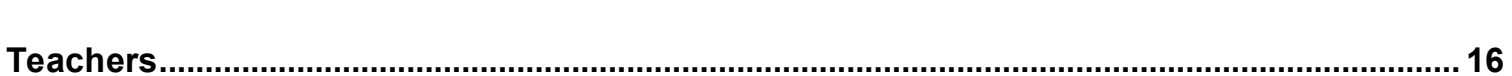

Benchmarks for Astronomy Lessons ……........................................................................ 17

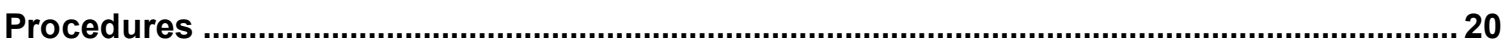

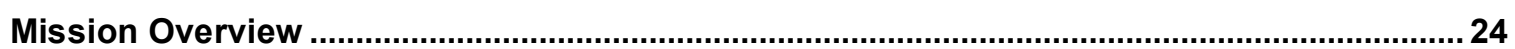

Survey Development.................................................................................................................. 27

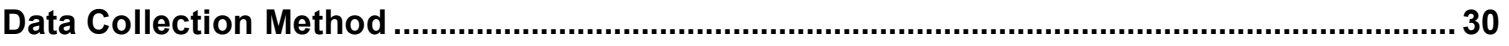

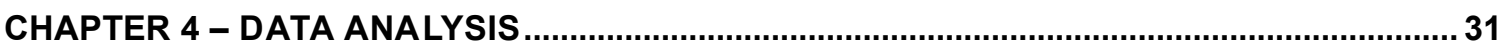

Presurvey Learning Preferences of Students in Inquiry-based and Traditionally-based

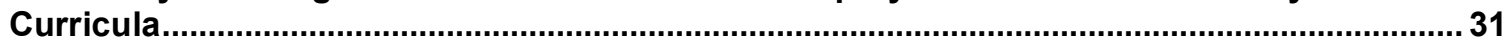

Pre- and Postsurvey Learning Preference Data for Students in Inquiry-based Curriculum 34 
Pre- and Postsurvey Learning Preference Data from Students in Traditionally-Based

Curriculum

Postsurvey Learning Preferences of Students in Inquiry-based and Traditionally-based

Curricula

Presurvey Attitude Towards Science of Students in Inquiry-based and Traditionally-based Curricula

Pre- and Postsurvey Attitude Towards Science Data for Students in Inquiry-based Curriculum.

Pre- and Postsurvey Attitude Towards Science Data for Students in Traditionally-based

Curriculum.

Postsurvey Attitude Towards Science of Students in Inquiry-based and Traditionally-based Curricula .

CHAPTER 5 - CONCLUSION

Analysis of Findings on Student Learning Preferences

Analysis of Findings on Students' Attitudes Towards Science ...........................................53

Related Results ........................................................................................................5

My Personal Observation .........................................................................................................57

Implications ...................................................................................................................................58

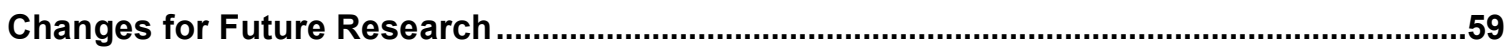

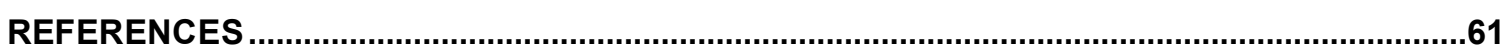

APPENDIX A LEARNING PREFERENCE AND ATTITUDE TOWARDS SCIENCE SURVEY FORM.

APPENDIX B INQUIRY LESSON PLANS

APPENDIX C TRADITIONAL LESSON PLANS

APPENDIX D PRESURVEY STATEMENTS ASSESSING THE LEARNING PREFERENCE OF THE INQUIRY-BASED AND TRADITIONALLY-BASED CURRICULUM STUDENTS

APPENDIX E PRESURVEY AND POSTSURVEY STATEMENTS ASSESSING THE LEARNING PREFERENCE OF THE INQUIRY-BASED CURRICULUM STUDENTS.

APPENDIX F PRESURVEY AND POSTSURVEY STATEMENTS ASSESSING THE LEARNING PREFERENCE OF THE TRADITIONALLY-BASED CURRICULUM STUDENTS.101 
APPENDIX G POSTSURVEY STATEMENT ASSESSING THE LEARNING PREFERENCE OF THE INQUIRY-BASED INSTRUCTED STUDENTS AND TRADITIONALLY-BASED

CURRICULUM STUDENTS.

APPENDIX H PRESURVEY STATEMENTS ASSESSING THE STUDENT ATTITUDE TOWARDS SCIENCE OF THE INQUIRY-BASED AND TRADITIONALLY-BASED CURRICULUM STUDENTS.

APPENDIX I PRE- AND POSTSURVEY STATEMENTS ASSESSING STUDENT ATTITUDE TOWARDS SCIENCE OF THE INQUIRY-BASED CURRICULUM STUDENTS.

APPENDIX J PRESURVEY AND POSTSURVEY STATEMENTS ASSESSING THE STUDENT ATTITUDE TOWARDS SCIENCE OF THE TRADITIONALLY-BASED CURRICULUM STUDENTS.

APPENDIX K POSTSURVEY STATEMENTS ASSESSING STUDENT ATTITUDE TOWARDS SCIENCE OF THE INQUIRY-BASED AND TRADITIONALLY-BASED CURRICULUM STUDENTS. 
(This page deliberately blank) 


\section{List of Tables and Figures}

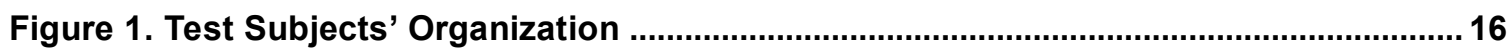

Table 1. National Science Education Standards (NSES) and the Corresponding Challenger

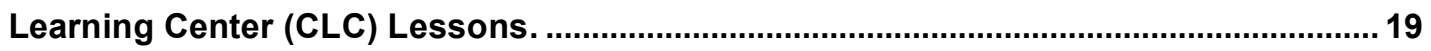

Table 2. General Timeline for Research Procedures ............................................................. 20

Table 4. Traditional learners' sequence of lesson plans and objectives .............................. 23

Table 5. Challenger Learning Center Job Descriptions........................................................ 26

Table 6. Statements on survey that assess students' attitude towards science..............29

Table7. Statements on survey that assess students' learning preferences in science

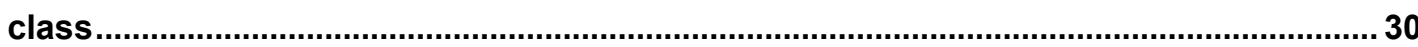

Table 8. Presurvey statements assessing the learning preference of the inquiry-based and traditionally-based curriculum students*.

Table 9. Pre- and postsurvey statements assessing the learning preference of the inquirybased curriculum students*.

Table 10. Pre- and postsurvey statements assessing the learning preference of the traditionally-based curriculum students*.

Table 11. Postsurvey statements assessing the learning preference of the inquiry-based and traditionally-based curriculum students*

Table 12. Presurvey statements assessing attitude towards science of the inquiry-based and traditionally-based curriculum students*

Table 13. Presurvey and postsurvey statements assessing attitude towards science of the students in the inquiry-based curriculum*.

Table 14. Pre- and postsurvey statements assessing attitude towards science of the students in the traditionally-based curriculum*

Table 15. Postsurvey statements assessing attitude towards science of the inquiry-based and traditionally-based curriculum students* 
(This page deliberately blank) 


\section{Chapter 1 - Statement of Topic and Its Importance}

During my undergraduate years I took an Ecology class that changed the way that I look at teaching and experiencing science. The class was offered by the Wild Rocky Field Institute at University of Montana. Their philosophy is to have students learn how to think critically about environmental issues, connect scientific knowledge with the landscape, and consider students' relationships to both natural and human communities. All of the courses are taught while traveling in the backcountry. The opportunity to perform scientific experiments, in which the findings were used by the West Yellowstone forestry department, had an additional impact on students because they could actually see how science works.

I promised myself after becoming a teacher that I would aim to provide an experience or field trip that would make science alive to children. The focus was experiential education that fit with the current curriculum as I began planning field trips for my students each year. In experiential education, students become more actively involved in the learning process than in traditional, didactic education. For example, going to a zoo and learning through observation and interaction with the zoo environment is experiential education, in contrast to reading and talking about animals in a classroom.

The focus of this research project will be based on research that was recently done in the United Kingdom by Jarvis and Pell. They researched the effect of the Challenger experience on elementary children's view of science and their motivation to seek careers in science, technology, or engineering. Their study was a longitudinal study in which different attitude scales were administered before, directly after, 2 months after, and 4-5 months after the simulated field trip (Jarvis \& Pell 2005). Using their research, I too will be examining at the affective value of the Challenger experience and to see if the type of teaching done in preparation for the simulated field trip has an impact on the attitudes of the subjects.

The Challenger Learning Center is a space-based learning environment where schoolchildren fly simulated space missions. The Challenger Learning Center features a mission control center modeled after the one at Johnson Space Center and an 
International Space Station simulator where experiments are performed and probes are "launched" into the depths of outer space. Students become a team of scientists and engineers acting as astronauts and mission controllers on a daring exploration of comets. Their goal is to successfully plot a rendezvous course with a comet, launch a probe, and collect scientific data on the object, giving students first-hand insight into teamwork, decision-making, and problem-solving skills.

The goals of the Challenger Learning Center will be looked at to see if they are accomplished after the simulated based field trip. The goals of the Challenger Learning Center are to

- Excite today's youth about the wonders of space and the adventure of a career in science, technology, engineering and mathematics — the so-called STEM careers.

- Give abstract concepts concrete meaning.

- Help students develop realistic processes of cooperation, communication, critical thinking, and problem solving.

- Help students pose questions and find pathways to answers (Challenger Center for Space Science Education, 2001).

Also within this research I would like to see the impact that inquiry-based curriculum versus traditionally-based curriculum has on students' attitudes toward science.

Mountain Ridge Middle School, the school that I currently teach at, is classified as an IB (International Baccalaureate) school. The seventh grade is composed of four teams; two IB teams, in which IB philosophy is implemented throughout all academic and nonacademic classes, and two teams that use a traditional approach to teaching curriculum. The science goals of Mountain Ridge Middle School are to meet and exceed Colorado state science standards. In addition to these goals, IB science classes implement IB science philosophy that aims to

- Develop inquiring minds and curiosity about science and the natural world. 
- Acquire knowledge, conceptual understanding and skills to solve problems and make informed decisions in scientific and other contexts.

- Develop scientific inquiry skills to design and carry out scientific investigations and evaluate scientific evidence to draw conclusions.

- Think analytically, critically and creatively to solve problems, judge arguments and make decisions in scientific and other context (International Baccalaureate Organization, 2000).

Having the different curriculum accessible within the school's science classes, makes it possible to study how different curricula affect students' attitudes in science.

\section{Research Questions}

1) Do student learning preferences differ depending upon the type of science curriculum they are in or as a result of completing an experiential-based field trip?

2) Do students' attitudes towards science depend upon the type of science curriculum they are in, or change as a result of completing an experiential-based field trip?

\section{Variable Definition}

1) Dependent variables: Students' attitude and interest in science outside of school and students' preferred learning methods.

2) Independent variables:

a. Experiential based field trip: content focused simulation field trip to the Challenger Learning Center (CLC)

b. Curriculum: inquiry based vs. traditionally-based.

\section{Measurement Tools}

A seventeen statement learning preference and attitude survey was prepared to measure the dependent variables (Appendix A). 


\section{Hypothesized Results}

It is my thought that learners in the inquiry-based curriculum will be more interested in statements that have to do with learning through inquiry methods. These statements within the survey include: I learn best by doing hands-on activities, I have more questions as a result of my learning, and I like discovering information on my own. I also feel that students taught using an inquiry curriculum will have a stronger aspiration to be scientists or engineers because, within the classroom they often are problem solving as if they are scientists. I also believe that traditional learners will enjoy learning through hands-on activities, but their interests in different learning preferences will not show a large difference as the inquiry learners will.

After students complete the astronomy unit and the field trip to the Challenger Learning Center, I believe that both learner groups will increase their overall attitude towards science. After students experience the simulated space mission at the Challenger Learning Center, their interest in seeking careers in a science or engineering field will also increase.

\section{Possible Effect of this Research}

Teachers and curriculum directors are always given the challenge of producing effective and lasting curriculum. This research will give a glimmer of light into how students prefer to learn science content and ways teachers can possibly change attitudes toward science. After the research is complete I will have a better understanding of how seventh graders prefer to learn science content. With the data collected, colleagues and I will work to develop curriculum within our school that meets the needs of our students. The data will also give Mountain Ridge Middle School a better understanding of what activities outside of the classroom will encourage students to view science as part of their everyday life. Finally, Mountain Ridge Middle School spends five thousand dollars a year sending students to the Challenger Learning Center; hopefully this research will give teachers and administration encouragement that the money is being spent effectively. 


\section{Chapter 2 - Literature Review}

Teachers of middle level students in science must be willing to improve students' attitudes towards science. The following review of current research identifies studies regarding popular trends in curriculum delivery, attitude towards science and experiential education.

\section{Students' Attitude Towards Science}

Substantial national concern has been expressed about the achievement and motivation of American students in math and science. The level of achievement of American students is less than that of students in some other industrialized countries (National Education Goals Panel, 1992). The Trends in International Mathematics and Science Study (TIMSS) provides reliable data on the mathematics and science achievement of U.S. students compared to that of students in other countries. Between the years 1995 and 2003 TIMSS reports show that eighth graders showed significant improvement in science performance (Gonzales, Guzman, \& Partelow, 2004). In 1995, US eighth graders were outperformed in science by eighth graders in nine counties that are surveyed by the TIMSS researchers. In 2003, US eighth graders were outperformed by students in five of these countries (Gonzales, Guzman, \& Partelow, 2004).

Meyers and Fouts (1992) examined the different types of science classroom environments in 27 high school classrooms and their relationship to attitudes towards science. Analysis showed that the 27 classrooms clustered into three groups. The cluster in which students displayed the most positive attitudes toward science was characterized by those classrooms exhibiting high student involvement, a strong positive relationship between classmates, personal support from the teacher, task oriented, and having wellestablished rules and organization. Classrooms in the cluster with the next highest positive attitude ranking toward science were characterized as having a low level of student involvement, but moderately strong positive relations among classmates. These classrooms were task oriented, competitive with good rule clarity, but the order and organization in the classrooms was low. Classrooms that displayed the lowest positive 
attitude toward science showed little student involvement, moderate positive relations between classmates, a moderate level of competition and organization with clear rules, and a vague idea of who was in firm control of the classroom (Meyers \& Fouts, 1992). The most influential classroom environment variables were those primarily related to the teacher. More negative attitudes toward science were found where the teacher had a great deal of control over the class and did not give students the freedom to explore on their own (Meyers \& Fouts, 1992).

Attitude scales give researchers the opportunity to measure more that just content absorbed in school. Jarvis and Pell (2002) were interested in measuring attitude because they felt a student's attitude helped in determining if he/she would be more likely to sustain learning and possibly want to pursue the subjects he/she would enjoy as a career. They developed an attitude instrument to assess children's attitudes in science. The general areas covered were: being in school, science experiments, and what I really think of science (Jarvis \& Pell, 2002).

One concern with the use of attitude scales is that results can be inconsistent, and provide weak results due to the way they are developed (Piburn, Sidlik, \& Mulvenon, 1992). As attitude scales are developed the statements are the perspective of a scholar rather than the students who would be surveyed. This leads to the question "Is it possible in principle for valid attitude constructs to arise elsewhere than in the minds who hold the attitudes (p3, Piburn, Sidlik, \& Mulvenon, 1992).”

In 2002, Jarvis and Pell developed an attitude scale for science education that has a reasonable reliability and validity. They broke their survey down into two categories: science enthusiasm and social context. The attitude survey was developed to examine changes in attitude towards science and the social context of science education. Also, the survey was used in research studies with the intention of studying the effects of the Challenger Learning Center on attitude changes in science (Jarvis \& Pell, 2002). 


\section{Inquiry vs. Traditional Curriculum}

Recent reform in science education has been focused on delivering content through an inquiry-based curriculum (Lederman, 1998). This approach to teaching curriculum is a shift from the more traditional teaching methods that require students to memorize facts, take notes, read textbooks, and answer rote questions at the end of chapters (Colburn, 2004).

The National Research Council (2000, p.1) defines inquiry as "the way in which scientists study the natural world and propose explanations based on the evidence derived from their work... but it is also... the activities of students during which they develop knowledge and understanding of scientific ideas (concept knowledge from the curriculum)." In inquiry teaching, students are given the chance to "discover" knowledge by exploring on their own. Teachers still direct the content according to the standards and objectives being addressed. Resources and an interesting, but focused, task are provided for the learners. Introductory tasks are designed to bring students to a commonality of basic information that they can then apply to more advanced tasks. As tasks become more student-centered, having students assess their work at the end of each activity (reflecting on how the activities are interrelated, what they could have done better, and how they could expand their investigations), and giving them time to try to improve their designs or try extensions enable students to make more connections between their previous and new knowledge (Colburn, 2004). Traditional teaching often has little to no real connection to students' life experiences or to situations in which they have been exposed to (Colburn, 2004). Inquiry-based teaching empowers students to explore their internal curiosity and to become independent learners.

Mattheis and Nakayama (1988) showed that inquiry-based science activities had positive effects on students' science achievement, cognitive development, laboratory skills, science process skills, and the understanding of science knowledge as a whole when compared to students taught using traditional approaches. Shirgley (1990) was able to show that students who use an inquiry approach to learning science have improved attitudes in science class and in school. This research indicates that an inquiry approach 
to learning is a more effective way for students to learn science; or, quite possibly, science learning improves when students' attitudes are positive.

\section{Experiential Education}

The Association for Experiential Education (AEE) defines experiential education as "student-centered learning in which the learner is actively engaged in posing questions, investigating, experimenting, being curious, solving problems, assuming responsibility, being creative, and constructing meaning” (AEE.). Student-centered learning is a learning process where much of the power during the experience resides with students and is appropriate for any age student (Colburn, 2004).

The importance of connecting personal experience to curriculum has been the focus of science education at least since John Dewey. Dewey stated "It is part of the educator's responsibility to see equally to things: First, that the problem grows out of the conditions of the experience being had in the present, and that it is with in the range of the capacity of students; and, secondly, that it is such that it arouses in the learner an active quest for information and for production of new ideas" (1938, p. 68). Dewy also stated that, "all genuine education comes about through experience" (Dewey, 1938). However, Dewey did not imply that all experiences were equally educative. Whether or not an experience is educative depends upon the quality of the experience, whether or not it is engaging to the student and if the experience has continuity with the student's further experiences (Dewey, 1938). Learning that is relevant to a student's life could motivate and develop skills to be productive members of society and possibly the scientific society.

Researchers Jarvis and Pell (2005) feel that it is vital for science students to develop an ability to think critically about scientific ideas and how they can be applied into every day lives.

The process of enabling young children to start a lifelong interest and understanding of science in the wider world may be improved by the provision of out-of-school science experiences. Museums, and particular 
science museums, are considered to have potential to fulfill a major role in this informal learning of science and technology.

(Jarvis \& Pell, 2005, p.980)

These experiences are also helpful in increasing students' understanding of what scientists do and how it can be used outside the classroom (Rennie \& McClafferty, 1995).

Crosby (1981) noted that the goal of education is for students to be able to understand and use experience, and this is achieved when students develop the critical thinking skills necessary to examine their experiences. Therefore, the teacher's role is to facilitate students' learning by engaging them in experiences that are fundamentally reflective because of their relevance to students' lives. "After resolution comes reflection on the experience so that what is learned may be generalized and used again" (Crosby, p. 12).

Horton and Hutchinson (2001) suggested, in an article entitled Nurturing Scientific Literacy Among Youth Through Experientially Based Curriculum Materials that curriculum materials should:

- include more emphasis on attitudes, problem solving, critical thinking, decision making, applications, technology and societal issues;

- provide appropriate experiences for targeted youth audiences;

- establish a relationship between content and experience.

Challenger Learning Center. The programs at the Challenger Learning Center are built on simulation methods inspired by the way NASA trains America's astronauts. Educational simulations are dynamic models of real-world activity designed to allow students to face authentic conditions and problem solve just as their professional counterparts must. The goal of the Challenger Learning Center is focused on the concept of an experiential-based curriculum.

The Challenger Center Founding Chairman June Scobee Rodgers explained the simulation philosophy by saying, "Kids learn through seeing and hearing and interacting 
and feeling. That's why they love computer games, scary or funny movies, and sports. When they're interacting with one another or working towards solving a problem in a team effort, they're using all their senses. Because they've personally participated, they can recall the lesson from their own experience, and that has much more impact than simply recalling facts they've read or heard." (Challenger Center for Space Science Education, 2001)

One study has been done on the impact of the Challenger Learning Center experiential field trip on students' attitude about space and science (Jarvis \& Pell, 2002). This study was completed over a period of 5 months, after 10 and 11 year old males and females visited the Challenger Learning Center in the United Kingdom. A survey assessing the students' attitudes toward space and science was administered four times; one month before the field trip, one week after the visit, two months after the field trip, and finally four months after the field trip. The survey had twenty-six statements that attempted to assess science enthusiasm, science in a social context, and space interest. Jarvis and Pell used the survey to see if students' attitudes toward science changed as a result of the Challenger Learning Center experience, and if their interest in seeking science as a career also increased (Jarvis \& Pell, 2005).

Jarvis and Pell found an increase in positive attitudes regarding science enthusiasm and space interest immediately after the trip to the Challenger Learning Center. By the fourth month of the study, interest in all three categories declined compared to the presurvey scores. The research also showed that girls had lower enthusiasm for science than boys. The mission to the Challenger Learning Center also had a large impact on students' interest in space immediately after the trip, but after 4 months, the interest in space actually was less than it was before the field trip for both girls and boys (Jarvis \& Pell, 2005).

Finally, the researchers found there was an increase in wanting to be a scientist immediately after the Challenger field trip, twenty-seven boys and thirty-one girls, changed their views in a positive manner. Again, after four months passed students who 
did not start out interested in a career in science returned to not having an interest in perusing a career in science, even after their interest was sparked by the visit to the Challenger Learning Center (Jarvis \& Pell, 2005). 
(This page deliberately blank) 


\section{Chapter 3 - Procedures}

The focus of this research was to see if different curricula, traditional verses inquiry, combined with an experiential-based field trip would improve students' attitude towards science and change their learning preferences.

Two general questions are being researched. The first question concerns student learning preferences: Do student learning preferences differ depending upon the type of science curriculum they are in or as a result of completing an experiential-based field trip? A survey was designed to address learning preferences by asking students if they preferred to learn through hands-on activities, reading information on their own, or by listening to someone talk to them.

Four sub-questions result from this general question and can be answered through administration of the survey to the students participating in the two different curricula before and after the experiential-based field trip to the Challenger Learning Center.

- Is there a difference in the learning preferences between inquiry and traditional curriculum students before the astronomy lessons and the field trip to the Challenger Learning Center?

- Is there a difference in learning preferences for inquiry curriculum students after the astronomy lessons and the field trip to the Challenger Learning Center?

- Is there a difference in learning preferences for traditional curriculum students after the astronomy lessons and the field trip to the Challenger Learning Center?

- Is there a difference in the learning preferences between inquiry and traditional curriculum students after the astronomy lessons and the field trip to the Challenger Learning Center?

The second general question concerns students' attitudes, which are influenced by interest in science outside of the classroom: Do student attitudes towards science change 
depending upon the type of science curriculum they are in or as a result of completing an experiential-based field trip? Doing science experiments at home, joining after school science clubs, reading books about science, or watching science television shows are examples of outside interests.

Four sub-questions also result from this general question.

- Do inquiry and traditional curriculum students' attitude towards science differ before the astronomy lessons and the field trip to the Challenger Learning Center?

- Is there a change in attitude towards science in inquiry curriculum students after the astronomy lessons and the field trip to the Challenger Learning Center?

- Is there a change in attitude towards science in traditional curriculum students after the astronomy lessons and the field trip to the Challenger Learning Center?

- Do inquiry and traditional curriculum students' attitude towards science differ after the astronomy lessons and the field trip to the Challenger Learning Center?

\section{Subjects}

The subjects for this study were 170 seventh grade students who attended Mountain Ridge Middle School in Colorado Springs, Colorado. Mountain Ridge Middle School is classified as an IB (International Baccalaureate) school. The $7^{\text {th }}$ grade is composed of four teams: two IB teams, in which IB philosophy is implemented throughout all academic and nonacademic classes, and two teams that use the traditional middle school curriculum. Teams are the organizational structure that creates opportunities for a group of teachers to work with a common set of students, allowing for collaboration among teachers, integration of the curriculum, and coordination of activities to best promote learning for every child. Only two of the four teams participated in this study, one traditional curriculum team (three classes) and one IB curriculum team (four classes). 
When students enter Mountain Ridge Middle school they are given the option to choose what curriculum team they would like to be on. If students choose an IB team this means they are required to take a foreign language for their three years at Mountain Ridge. The science goals for all four teams at Mountain Ridge Middle School are to meet and exceed Colorado state science standards. In addition to these goals, IB science classes implement IB science philosophy which aim to

- Develop inquiry minds and curiosity about science and the natural world.

- Acquire knowledge, conceptual understanding and skills to solve problems and make informed decision in scientific and other context.

- Develop skills of scientific inquiry to design and carry out scientific investigations and evaluate scientific evidence to draw conclusions.

- Think analytically, critically and creatively to solve problems, judge arguments and make decisions in scientific and other context (2000).

If students choose a traditional team they have the option to take a foreign language but are not required to.

From 2001 through 2004 the IB program at Mountain Ridge Middle School was an exclusive program in which students were interviewed and met specific academic requirements. Because of these standards, the community saw this program as a high achieving program. Since 2005, the entrance requirements have been removed and any student who is willing to take a foreign language for three years can enter the program. Even though the entrance requirements have been excluded, a large number of students who participate in the IB program tend to be higher achieving students compared to students who participate in the traditional program at Mountain Ridge Middle School. For example twenty percent of students in IB classes are classified as talented and gifted students, where as traditional classes have about two percent of students who are talented and gifted. 
Figure 1. Test Subjects' Organization

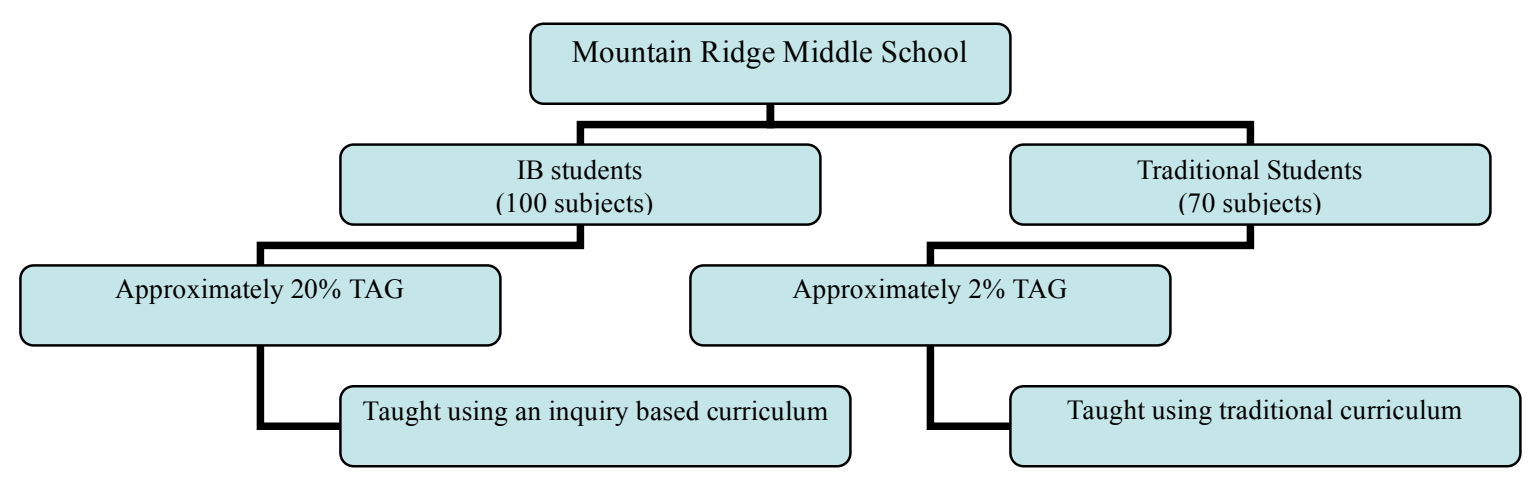

All subjects participated in a three week curriculum that focused on astronomy as preparation for an experiential-based field trip to the Challenger Space Center. One hundred of the students (four classes of IB students) received the astronomy lessons organized from an inquiry perspective. A separate group of seventy students (three classes of traditional students) received the lessons organized in a more traditional manner. All participating classes went to the Challenger Learning Center with their science classes, one day at a time over a two week period after the astronomy curriculum was complete.

\section{Teachers}

The two participating teachers taught general science on two different teams at Mountain Ridge Middle School. The teacher who taught the IB team (four classes) used a block schedule, which means one science class is 90 minutes long but only meets every other day. The teacher who taught the traditional curriculum team (three classes) used a regular schedule, in which a science class is 45 minutes long but meets every day. This schedule applies to all teachers within their specific team.

The two teachers who participated in the study have used the same methodologies to teach the Challenger Learning Center curriculum as they used to teach other science 
curriculum throughout the whole school year. For example the IB team teacher used inquiry-based lessons on this unit and also used inquiry-based lessons throughout the school year. This teacher had a student centered classroom the whole school year, in which students often develop their own questions to lessons that would lead into an investigation. For example, in a unit done on alternative energy sources, students within a group were asked to build a solar cooker that would attain the highest temperature, using a pizza box and other material of their choice. Once the solar cookers were built students had to develop a scientific experiment using their solar cooker and another one built in the class to answer their research question.

The traditional team teacher who used more traditional methods to teach the astronomy mission prep lessons for the field trip also used traditional methods throughout the school year. This teacher had a more teacher centered classroom all year long, in which the students progressed through the same material at the same speed. The material was presented through reading a textbook, notes developed by the teacher, and answering questions at the end of sections in the textbook. For example, when learning about alternative energy sources, students were assigned to read two sections in their textbook, answer questions at the end of each section and complete a quiz. This method of learning is usually done individually, where the students work silently on assigned work.

\section{Benchmarks for Astronomy Lessons}

The key to each student's learning experience at the Challenger Learning Center is the preparation that takes place in the classroom in the weeks leading up to the experientialbased field trip. An instructional unit was provided by the Challenger Learning Center (Challenger Center for Space Science Education, 2001) to address the benchmarks listed below. Different teachers used different methods to teach the astronomy lessons provided by the Challenger Learning Center (see appendix B and $\mathrm{C}$ for specific differences). The unit consisted of five lessons that can be taught over a nine day period, based on a 45 minute class period. Table 1 shows five lessons of the unit that provide scientifically sound, educationally rich activities that were developed to by NASA Discovery Mission Program, the Jet Propulsion Laboratory's STARDUST Mission, and classroom teachers, 
to meet the National Science Standards (Challenger Center for Space Science Education, 2001).

The Challenger Learning Center's educational pedagogy promotes scientific literacy by encouraging exploration, inquiry, and exciting young people about knowledge and learning. Their curriculum also provides a student centered environment in which the essence of learning is exploration (Challenger Center For Space Science Education, 2001). The Challenger Center programs are designed to reflect academic standards such as the National Science Education Standards by the National Research Council (Challenger Center for Space Science Education, 2001). 
Table 1. National Science Education Standards (NSES) and the Corresponding Challenger Learning Center (CLC) Lessons.

\begin{tabular}{cll}
\hline NSE Standards & NSE Substandard & CLC Lessons \\
\hline Unifying Concepts & Systems, order, and & Famous Comet, Cookin' \\
and & organization & Up a Comet, Cometary \\
& & Orbits, Investigating \\
& & Falling Particles \\
& Evidence, modes and & Famous Comet, Cookin' \\
& explanation & Up a Comet, Cometary \\
& & Orbits, Investigating \\
& Change, constancy, and & Falling Particles \\
& measurement & Investigating Falling \\
Science as Inquiry & Abilities necessary to do & Particles \\
& scientific inquiry & Investigating Falling \\
& & Particles \\
& Understanding about & Cooking Up a Comet, \\
& scientific inquiry & Investigating Falling \\
Science in Personal & Science and technology in & Famous Comets, \\
and Social & society & Particles \\
Perspectives & & Famous Comets, \\
Technology & Science and technology & Investigating Falling \\
& & Particles \\
\hline
\end{tabular}

Challenger Center for Space Science Education, 2001, p v. 


\section{Procedures}

The goal of the astronomy unit was to prepare both traditional and IB curriculum students for a space mission at the Challenger Learning Center. The content covered in the two weeks before the simulation-based field trip was presented in the context of a realistic space exploration. Two different curriculum approaches were used to prepare students for the experiential-based field trip. One approach used traditional curriculum organization that included giving students notes, reading text books and answering rote questions.

Table 2. General Timeline for Research Procedures

\begin{tabular}{ll}
\hline Week & Activity \\
\hline Week 1-3 ( Beginning of & Astronomy unit plan development \\
Week 4 (Middle March) & Inquiry and Traditional. \\
Week 8 (Middle of April) & Begin teaching Astronomy unit. \\
& directly relates to the Challenger \\
& mission, and hand out presurveys to \\
& traditional and inquiry taught \\
& students. \\
Week 10 (Beginning of May) & Attend the Challenger Space \\
& Mission one class, 30 students, each \\
& day. On Friday after each class has \\
& Successfully completed the \\
& Challenger Mission postsurvey.
\end{tabular}


The other approach was an inquiry-based curriculum, which took place when the teacher created a student centered learning environment. In this learning environment students were actively engaged in learning to use critical thinking skills and science processes to answer questions that came from their prior knowledge and experiences.

After two weeks of preparation for the experiential-based field trip, both sets of students went to The Challenger Learning Center to complete the mission "Rendezvous with a Comet”. For no specific reason, the traditional students went the first week and inquiry students went the following week.

Inquiry Lesson Sequence. Students in the inquiry-based curriculum completed a sequence of eleven lessons. (Table 3; Appendix B, detailed lesson plans) 


\section{Table 3. Inquiry learners' sequence of lesson plans and objectives}

\begin{tabular}{|c|c|c|}
\hline Day & Activity & Objective \\
\hline One \& Two & $\begin{array}{l}\text { Differences of Comets, } \\
\text { Meteors and } \\
\text { Asteroids }\end{array}$ & $\begin{array}{l}\text { Students will be able to analyze and identify a list of } \\
\text { characteristics pertaining to comets, meteors, and } \\
\text { asteroids. }\end{array}$ \\
\hline Three & Cookin' Up a Comet & Compare the parts of the model to the parts of a comet. \\
\hline Four \& Five & $\begin{array}{l}\text { Famous Comet } \\
\text { Research }\end{array}$ & $\begin{array}{l}\text { Research and compare two comets and identify } \\
\text { differences, such as eccentricity, perihelion, term of } \\
\text { comet. }\end{array}$ \\
\hline $\begin{array}{l}\text { Six \& } \\
\text { Seven }\end{array}$ & Cometary Orbits & Create ellipses and use them as models of real orbits. \\
\hline $\begin{array}{l}\text { Eight \& } \\
\text { Nine }\end{array}$ & $\begin{array}{l}\text { Investigating Falling } \\
\text { Particles }\end{array}$ & $\begin{array}{l}\text { Apply mathematics to determine properties of ellipses. } \\
\text { Compare the orbits of planets and comets. } \\
\text { Examine what happens to a ball of clay that is dropped } \\
\text { from different heights. } \\
\text { Brainstorm various mediums to collect falling particles } \\
\text { with-out changing the characteristics of the captured } \\
\text { particles. }\end{array}$ \\
\hline Ten & $\begin{array}{l}\text { Challenger Learning } \\
\text { Center experiential } \\
\text { trip. }\end{array}$ & $\begin{array}{l}\text { Successfully complete the mission Rendezvous with a } \\
\text { Comet. }\end{array}$ \\
\hline Eleven & $\begin{array}{l}\text { Mission debriefing and } \\
\text { postsurvey } \\
\text { administered }\end{array}$ & $\begin{array}{l}\text { Students will reflect on the accomplishments of the } \\
\text { mission Rendezvous With a Comet, and each } \\
\text { student's specific job at the Challenger Learning } \\
\text { Center. }\end{array}$ \\
\hline
\end{tabular}


Traditional Lesson Sequence. Students in the traditionally-based curriculum completed a sequence of nine lessons. (Table 4; Appendix C, detailed lesson plans)

\section{Table 4. Traditional learners' sequence of lesson plans and objectives}

\begin{tabular}{|c|c|c|}
\hline Day & Activity & Objective \\
\hline One \& Two & $\begin{array}{l}\text { Differences between } \\
\text { Comets, Meteors and } \\
\text { Asteroids }\end{array}$ & $\begin{array}{l}\text { Students will be able to analyze and identify a list of } \\
\text { characteristics pertaining to comets, meteors, and } \\
\text { asteroids. }\end{array}$ \\
\hline Three \& Four & Famous Comet Project & $\begin{array}{l}\text { Students will research a comet that is historically, } \\
\text { scientifically, or otherwise significant and create a } \\
\text { collage or poster to communicate their research findings. } \\
\text { Students will be able to: }\end{array}$ \\
\hline Five \& Six & Cometary Orbits & $\begin{array}{l}\text { Identify the geocentric and heliocentric systems. } \\
\text { Recognize how scientists such as Copernicus, Galileo, } \\
\text { and Kepler contributed to acceptance of the heliocentric } \\
\text { Identify the objects that make up the solar system. } \\
\text { Students will be able to: }\end{array}$ \\
\hline Seven & $\begin{array}{l}\text { Investigating Falling } \\
\text { Particles }\end{array}$ & $\begin{array}{l}\text { Examine what happens to a ball of clay that is dropped } \\
\text { from different heights. } \\
\text { Measure the height, depth, and width of a clay ball } \\
\text { before and after a drop. }\end{array}$ \\
\hline Eight & $\begin{array}{l}\text { Challenger Learning } \\
\text { Center experiential trip. }\end{array}$ & $\begin{array}{l}\text { Successfully complete the mission Rendezvous with a } \\
\text { Comet }\end{array}$ \\
\hline Nine & $\begin{array}{l}\text { Mission debriefing and } \\
\text { postsurvey administered }\end{array}$ & $\begin{array}{l}\text { Students will reflect on the accomplishments of the } \\
\text { mission Rendezvous With a Comet, and each student's } \\
\text { specific job at the Challenger Learning Center. }\end{array}$ \\
\hline
\end{tabular}




\section{Mission Overview}

The Challenger Mission Prep manual explains Rendezvous with a Comet's mission as the following:

In the not-too-distant future, teams of scientists are routinely using small, maneuverable space stations to venture out into Earth's "neighborhood" as part of a long-term study of small bodies in the Solar System. Primary targets include comets and asteroids, which scientists believe are the oldest, most primitive bodies in the Solar System and may preserve the earliest record of the material that formed Earth and its planetary neighbors.

During this mission, team members work as scientists and engineers headed to Rendezvous with a Comet as part of this continued study of our Solar System. These rendezvous missions are critical in helping scientists verify and better understand data collected by earlier small body missions occurring at the start of the new Millenium, such as STARDUST and its planned capture of cometary material from comet Wild-2 in 2004 and the return of that material to Earth in 2006. The actual samples provided by STARDUST established detailed baseline data on comets still used today. The onboard astronauts, working with their counterparts in Mission Control, are tasked with sending a probe to intercept and collect new data in a well-studied short-period comet before heading on for a continued study of the asteroid Ceres, the largest known asteroid at 623 miles $(1,003$ $\mathrm{km})$ in diameter.

Comet Enke provides an excellent target because its short period (3.3 years) has allowed it to be observed from Earth at more apparitions (or appearances) than any other comet, including the famous Comet Halley. Encke continues to puzzle scientists because even though it has been in a short-period orbit for thousands of years, the comet continues to have a high level of activity as the Sun's heat boils off its dirty ice into gases and dust. This is the first probe to rendezvous with Encke since 2003 and the fly-by of the comet-chasing CONTOUR spacecraft.

The small, maneuverable space stations used for these rendezvous missions require lots of maintenance and care, providing plenty of challenges for the crews in space and on the ground. Navigating into the correct position for probe launches - not to mention sending a probe through the material surrounding an active comet - also requires concentration and teamwork to successfully collect vital scientific information and complete the mission.

Small bodies in the Solar System are also highly unpredictable objects and have been known to surprise scientists from time to time, so crew members will also need to be alert and ready to make quick decisions (pg, ii Challenger Center For Space Science Education, 2001). 
As students completed the above scenario they had to participate in specific jobs within the simulation. Each job was needed for a successful completion of the mission. Students filled out an application noting their skills and preferences for a specific job. Teachers used the applications to place students in a job that was most suited for them. Table 5 shows the job descriptions. 


\section{Table 5. Challenger Learning Center Job Descriptions}

\begin{tabular}{|c|c|}
\hline Position & Job description for Rendezvous with a Comet \\
\hline Communications & Maintains the communication link between Mission Control and \\
\hline \multirow[t]{2}{*}{ Officer } & Space Station. \\
\hline & Uses correct protocol to communicate effectively. \\
\hline \multirow[t]{3}{*}{ Data Officer } & Controls cameras onboard Space Station. \\
\hline & Establishes printed communication between Mission Control and \\
\hline & the Space Station by sending messages via the computer. \\
\hline \multirow[t]{3}{*}{ Navigation Team } & Clear star fields in order to rendezvous with a comet. \\
\hline & Triangulates the position of the comet. \\
\hline & Launches particle detectors to determine the most active part of the \\
\hline \multirow[t]{3}{*}{ Remote Team } & Compares meteoroid and plant samples inside a glove box. \\
\hline & Collects and analyzes data using mass, volume, density and \\
\hline & chromatography. \\
\hline \multirow[t]{3}{*}{ Probe Team } & Uses effective communication between team members in order to \\
\hline & build a probe within a specified time constraint. \\
\hline & Responsible for assembly, deployment and monitoring probe. \\
\hline Medical & $\begin{array}{l}\text { Responsible for monitoring and analyzing the physical condition of } \\
\text { the crew. }\end{array}$ \\
\hline \multirow[t]{3}{*}{ Life Support } & Monitors the Space Station environment by accurately reading \\
\hline & instrument gauges to ensure the safety of the flight crew. \\
\hline & Maintains a safe spacecraft environment even during emergencies. \\
\hline \multirow[t]{3}{*}{ Isolation } & Researches and analyzes data of meteoroids, radioactive and \\
\hline & hazardous material. \\
\hline & Isolates hazardous materials in container. \\
\hline
\end{tabular}




\section{Survey Development}

A one page survey was prepared to assess the students' preferred method of learning and their attitude towards science (Appendix A). The one page survey was based on an attitude survey developed by Jarvis and Pell (2002) for a similar study done in the United Kingdom. Generally, research in science education measures understanding of content, not attitudes (Jarvis \& Pell, 2002). There have been no documented attempts to measure the affective value of inquiry verses traditional-based teaching methods that also included an experiential-based field trip.

Jarvis and Pell's (2002) survey was distributed across three topics: science enthusiasm, social context, and space. Science enthusiasm statements focused on the students' interest in science outside of a science classroom. Doing science experiments at home, joining after school science clubs, reading books about science or watching science television shows are examples of outside interests. Social context statements assessed how important science was in everyday life. These statements varied from how good science was for everyone to the amount of money that should be spent on science research. The final category was space. These statements evaluated students' knowledge on space exploration. The Jarvis and Pell attitude survey was piloted several times and found to be quite reliable $(.65<\alpha<.78)$ (Jarvis \& Pell, 2002). Alpha reliability is regarded as a measure of internal consistency of the mean of the items at the time of administration of a survey. The survey has to be administered on two or more occasions. Generally, alpha reliabilities above .70 are considered good. The good alpha reliability shown in this survey demonstrates that the students responded consistently to the survey items.

All the science enthusiasm statements from Jarvis and Pell's attitude survey (2002) were employed in this study. These statements assessed if students were interested in science outside of the classroom by choosing to read, experiment, join after school science clubs, and watch science television programs (Table 6).

Also included in the survey were seven statements focusing on subjects' preferences in learning science content. Table 7 shows the statements that were designed to focus on students' enjoyment of doing hands-on learning, or if they would rather read or listen to 
another person talk about science concepts. These statements were not from Jarvis and Pell's study. The statements were developed by the researcher as a way to measure the methods in which students prefer to learn scientific information. This data will assist the researcher in finding out if students prefer learning through inquiry or traditionally, but could be useful to the researcher for her personal lesson planning. No alpha reliability was established for these seven statements. 


\section{Table 6. Statements on survey that assess students' attitude towards science}

8. Science is an exciting learning experience.

9. I enjoy seeing how the information learned in science class can be used outside of school.

10. I would like to be a scientist or engineer.

11. I often do science experiments at home.

12. School science clubs are a good idea.

13. I would like to be given a science kit as a present.

14. I like science more than any other school work.

15. I like to watch science programs on TV.

16. I am always reading science stories.

17. One day I would like to go to the moon.

(Jarvis \& Pell, 2002)

The seventeen statement survey was administered using a four point scale in which the subjects were able to strongly agree, agree, disagree, strongly disagree. A fifth option, does not apply, was made available to give students the choice to not respond to the statements. When the data was analyzed, each of these responses was given a numerical value: strongly disagree (1), disagree (2), agree (3), and strongly agree (4). The "does not apply" option was not given a numerical value. 
Table7. Statements on survey that assess students' learning preferences in science class

1. I learn best when I read a book or find information on my own.

2. I learn best when I listen to someone talk about the topic I am trying to learn.

3. I learn best when I do hands-on activities.

4. I like it when teachers ask questions instead of giving me answers.

5. I like discovering information on my own.

6. I would consider a career in science or engineering.

7. I find I have more questions as a result of my learning.

\section{Data Collection Method}

Both teachers participating in this study agreed to give the survey before the students began the curriculum unit in preparation for the field trip to Challenger Learning Center. The surveys were administered at the beginning of the class period by the teacher who was going to be teaching the lessons. This was done before any lessons had been taught. The day after completing the mission at Challenger Learning Center students were administered the same survey, by the same teacher, to measure if the variables being studied had any effect on students' attitude in science and their learning preference. (Appendix A) Students who were not present on the day the surveys were administered did not participate in the pre- or postsurvey. 


\section{Chapter 4 - Data Analysis}

Subjects were asked to participate in a survey containing seventeen statements about preferences in learning and attitudes towards science. Pre- and postsurvey were given to determine if a change occurred within the variables being tested. The Likert scale used on the surveys ranged from: strongly disagree (1), disagree (2), and agree (3), to strongly agree (4). One more choice, does not apply, was given to subjects but was not calculated in the mean and standard deviation. Does not apply responses are shown in the raw data in Appendix D-K. The subject groups participating in the study differed in the way the astronomy curriculum was taught to them. One group was taught using a traditionally organized curriculum, whereas the other group was taught using an inquiry organized curriculum.

Results of the survey are presented by first examining students' preference in learning curriculum. The data tables compare traditional and inquiry-based learners' pre- and postsurvey data and the difference between the inquiry learners' pre- and postsurvey and traditional learners' pre- and postsurvey data. Second, the data is examined with respect to students' attitudes towards science before and after the astronomy curriculum combined with the Challenger experiential field trip. Data tables will compare the difference between each curriculum group survey data and traditional and inquiry-based learner survey data.

\section{Presurvey Learning Preferences of Students in Inquiry-based and Traditionally-based Curricula}

The first thing that will be examined is the preferences that students have towards learning the science curriculum. The presurvey was administered to students in both groups prior to the astronomy lessons and the field trip to the Challenger Learning Center.

Presurvey Data. Data was collected in the presurvey that allowed the contrast between the inquiry-based curriculum students with the traditionally-based curriculum students to determine their preferences in learning. Raw data used to produce these tables can be 
found in Appendix D. Both groups of learners, inquiry and traditional, showed the most interest in learning through hands-on activities compared to reading a book, finding information on their own and listening to someone talk. Table 8 shows mean scores for both learner groups were very similar, 3.58 and 3.43 on the presurvey.

Table 8. Presurvey statements assessing the learning preference of the inquiry-based and traditionally-based curriculum students*.

\section{Survey Statement}

1. I learn best when I read a book or find information on my own.

2. I learn best when I listen to someone talk about the topic I am trying to learn.

3. I learn best when I do hands-on activities.

4. I like it when teachers ask questions instead of giving me answers.

5. I like discovering information on my own.

6. I would consider a career in science or engineering.

7. I find that I have more questions as a result of my learning.

Presurvey Effect Size. Effect size describes how large the relationship is between two variables (Bracey, 2000, Shaver, 1985). Bracey devised a formula for calculating the effect size by subtracting the mean score of the control group from the mean score of the 
experimental group and dividing by the standard deviation of the control group (Bracey, 2000). The formula for effect size is as follow:

$$
\text { Effect Size }=\frac{\bar{X}_{\text {experimental group }}-\bar{X}_{\text {control group }}}{S_{\text {controlgroup }}}
$$

For the purposes of this research, the experimental group will be the group that has received the treatment (inquiry-based instruction or experiential field trip). Thus in three cases the traditional group will be the control group and the inquiry group experimental group. In the one instance where the inquiry group is the only group being compared, the pre-experiential inquiry group will be the control group and the post-experiential inquiry group will be the experimental group. The following is an example of an effect size calculation using the average data from Table 8:

$$
\begin{aligned}
& \text { Effect Size }=\frac{\bar{X}_{\text {inquiry group }}-\bar{X}_{\text {trad group }}}{S_{\text {trad group }}} \\
& \text { Effect Size }=\frac{2.70-2.68}{.79} \\
& \text { Effect Size }=.03
\end{aligned}
$$

Generally the larger the effect size, the greater the impact of an intervention (Bracey,2000). Bracey suggest that an effect size of 1.00 is seldom seen in educational research and the effect sizes "between +.2 and +.3 begin to take on practical significance" (Bracey, 2000, p.60). For the purposes of my research data, I have decided that an effect size scale of 0.30-0.50 would be of moderate importance, $0.10-0.30$ would be of small importance, and anything smaller than 0.10 would be considered purely chance occurrence.

The aggregate effect size for learning preference between inquiry-based learners and traditionally-based learners shown in Table 8 is .03 . 


\section{Pre- and Postsurvey Learning Preference Data for Students in Inquiry- based Curriculum}

Data was also collected in the presurvey and postsurvey that permitted capture of any leaning preference changes resulting from the combination of the astronomy unit and the Challenger Learning Center field trip by students in the inquiry-based curriculum.

Data. The results of learning preferences between the presurvey and postsurvey for the inquiry-based learners are shown in Table 9. Raw data used to produce these tables can be found in Appendix E. Notice all the scores increased from the presurvey to the postsurvey except for statement 3 "I learn best when I do hands on activities". The differences between the pre- and postsurvey for this statement were minimal.

Effect Size. The aggregate effect size for learning preference between the presurvey and postsurvey for the inquiry-based learners in Table 9 is 0.15 . 
Table 9. Pre- and postsurvey statements assessing the learning preference of the inquiry-based curriculum students*.

\begin{tabular}{llllll}
\hline & & \multicolumn{2}{c}{ Presurvey } & \multicolumn{2}{c}{ Postsurvey } \\
\cline { 3 - 6 } Survey Statement & N & Mean & SD & Mean & SD \\
1. I learn best when I read a book or & 100 & 2.34 & .75 & 2.46 & .90 \\
find information on my own. & & & & & \\
2. I learn best when I listen to & 100 & 2.81 & .75 & 2.85 & .78 \\
$\quad$ someone talk about a topic I am & & & & & \\
\\
learning.
\end{tabular}

$\begin{array}{lllllll}\text { 3. I learn best when I do hands on } & 100 & 3.58 & .62 & 3.57 & .68\end{array}$ activities.

$\begin{array}{llllllll}\text { 4. I like it when teachers ask } & & 100 & 2.52 & .81 & 2.56 & .82\end{array}$ questions instead of giving me answers.

$\begin{array}{lllllll}\text { 5. I like discovering information on } & 100 & 2.49 & .85 & 2.65 & .89\end{array}$ my own.

$\begin{array}{lllllll}\text { 6. I would consider a career in } & & 100 & 2.35 & .96 & 2.70 & .96\end{array}$ science or engineering.

$\begin{array}{lllllll}\text { 7. I find that I have more questions } & 100 & 2.80 & .73 & 2.96 & .76\end{array}$ as a result of my learning.

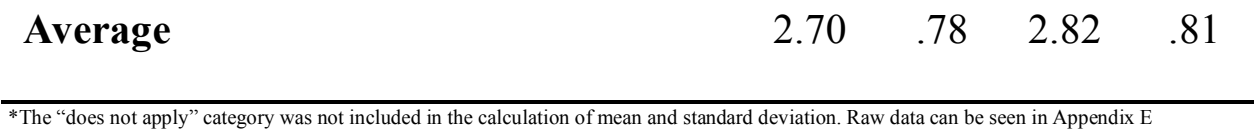




\section{Pre- and Postsurvey Learning Preference Data from Students in Traditionally-Based Curriculum}

Data was collected in the presurvey and the postsurvey that permitted capture of any learning preference changes resulting from the combination of the astronomy unit and the Challenger Learning experience by the traditionally-based curriculum students.

Data. The results of learning preferences between the presurvey and postsurvey among the traditionally-based learners are shown in Table 10. Raw data used to produce these tables can be found in Appendix F. All the scores increased from the presurvey to the postsurvey except for statement 1 and 5 . In statement 1 , there was a notable decrease in mean scores between the pre- and postsurvey, but in statement 5 the difference was minimal.

Effect Size. The aggregate effect size for learning preference between the presurvey and postsurvey for traditionally-based learners shown above in Table 10 is 0.09 . 
Table 10. Pre- and postsurvey statements assessing the learning preference of the traditionally-based curriculum students*.

\begin{tabular}{|c|c|c|c|c|c|}
\hline \multirow[b]{2}{*}{ Survey Statement } & \multirow[b]{2}{*}{$\mathbf{N}$} & \multicolumn{2}{|c|}{ Presurvey } & \multicolumn{2}{|c|}{ Postsurvey } \\
\hline & & Mean & SD & Mean & SD \\
\hline 1. I learn best when I read a book & 70 & 2.77 & .78 & 2.61 & .82 \\
\hline \multicolumn{6}{|l|}{ or find information on my own. } \\
\hline 2. I learn best when I listen to & 70 & 2.71 & .89 & 2.91 & .82 \\
\hline \multicolumn{6}{|l|}{ someone talk about the topic I } \\
\hline \multicolumn{6}{|l|}{ am trying to learn. } \\
\hline 3. I learn best when I do hands on & 70 & 3.43 & .55 & 3.44 & .69 \\
\hline \multicolumn{6}{|l|}{ activities. } \\
\hline 4. I like it when teachers ask & 70 & 2.34 & .75 & 2.43 & .90 \\
\hline \multicolumn{6}{|l|}{ questions instead of giving me } \\
\hline \multicolumn{6}{|l|}{ answers. } \\
\hline 5. I like discovering information & 70 & 2.67 & .86 & 2.62 & .87 \\
\hline \multicolumn{6}{|l|}{ on my own. } \\
\hline 6. I would consider a career in & 70 & 2.09 & .94 & 2.40 & .95 \\
\hline \multicolumn{6}{|l|}{ science or engineering. } \\
\hline 7. I find that I have more questions & 70 & 2.74 & .74 & 2.83 & .72 \\
\hline \multicolumn{6}{|l|}{ as a result of my learning. } \\
\hline Average & & 2.77 & .76 & 2.81 & .80 \\
\hline
\end{tabular}

*The "does not apply" category was not included in the calculation of mean and standard deviation. Raw data can be seen in Appendix F 


\section{Postsurvey Learning Preferences of Students in Inquiry-based and Traditionally-based Curricula}

The final learner preferences data that was collected is the postsurvey that allows the contrast between the inquiry-based instructed students with the traditionally-based instructed students to determine their preferences in learning style.

Data. The results of the postsurvey are shown in Table 11. Raw data used to produce these tables can be found in Appendix G. Once again both groups of learners, inquiry and traditional, showed the most interest in learning through hands-on activities compared to reading a book, finding information on their own and listening to someone talk. Table 11 shows students mean scores for both learner groups were very similar, 3.57 and 3.44, on the post survey. These mean scores were considerably larger than the other learning preferences listed in the survey. Also, inquiry-based learners' scores were higher than traditional-based learners for statements 3 through statement 7 .

Effect Size. The aggregate effect size for learning preference between the postsurvey data for inquiry-based and traditionally-based learners shown in Table 11 is 0.09 . 
Table 11. Postsurvey statements assessing the learning preference of the inquiry-based and traditionally-based curriculum students*.

\begin{tabular}{|c|c|c|c|c|c|c|}
\hline \multirow[b]{2}{*}{ Survey Statement } & \multirow[b]{2}{*}{$\mathbf{N}$} & \multicolumn{2}{|c|}{ Inquiry } & \multicolumn{2}{|c|}{ Traditional } & \multirow[b]{2}{*}{ SD } \\
\hline & & Mean & SD & $\mathbf{N}$ & Mean & \\
\hline 1. I learn best when I read a book & 100 & 2.46 & .90 & 70 & 2.61 & .82 \\
\hline \multicolumn{7}{|l|}{ or find information on my own. } \\
\hline 2. I learn best when I listen to & 100 & 2.85 & .78 & 70 & 2.91 & .82 \\
\hline \multicolumn{7}{|l|}{ someone talk about the topic I } \\
\hline \multicolumn{7}{|l|}{ am trying to learn. } \\
\hline 3. I learn best when I do hands on & 100 & 3.57 & .68 & 70 & 3.44 & .69 \\
\hline \multicolumn{7}{|l|}{ activities. } \\
\hline 4. I like it when teachers ask & 100 & 2.56 & .82 & 70 & 2.43 & .90 \\
\hline \multicolumn{7}{|l|}{ questions instead of giving me } \\
\hline \multicolumn{7}{|l|}{ answers. } \\
\hline 5. I like discovering information & 100 & 2.65 & .89 & 70 & 2.62 & .87 \\
\hline \multicolumn{7}{|l|}{ on my own. } \\
\hline 6. I would consider a career in & 100 & 2.70 & .96 & 70 & 2.40 & .95 \\
\hline \multicolumn{7}{|l|}{ science or engineering. } \\
\hline 7. I find that I have more questions & 100 & 2.96 & .76 & 70 & 2.83 & .72 \\
\hline \multicolumn{7}{|l|}{ as a result of my learning. } \\
\hline Average & & 2.82 & .83 & & 2.75 & .82 \\
\hline
\end{tabular}




\section{Presurvey Attitude Towards Science of Students in Inquiry-based and Traditionally-based Curricula}

Ten statements were posed on the survey to assess students' attitude towards science. Data was collected that permitted the contrast of students' attitude towards science between the inquiry-based curriculum students with traditionally-based curriculum students. The survey was administered to both groups prior the astronomy lessons and field trip to the Challenger Learning Center.

Data. The results of the presurvey are shown in Table 12. Raw data used to produce these tables can be found in Appendix H. Inquiry-based learners' scores were generally higher than the traditional based learners' scores. Statement 11 was the only statement in which traditional learners' mean score was higher than inquiry learners' scores.

Effect Size. The aggregate effect size for attitude towards science for the presurvey data between students in the inquiry-based and traditionally-based curriculum in Table 12 is 0.13 . 
Table 12. Presurvey statements assessing attitude towards science of the inquiry-based and traditionally-based curriculum students*.

\begin{tabular}{|c|c|c|c|c|c|c|c|}
\hline \multirow{2}{*}{\multicolumn{2}{|c|}{ Survey Statement }} & \multicolumn{3}{|c|}{ Inquiry } & \multicolumn{3}{|c|}{ Traditional } \\
\hline & & $\mathbf{N}$ & Mean & SD & $\mathbf{N}$ & Mean & SD \\
\hline 8. & $\begin{array}{l}\text { Science is an exciting learning } \\
\text { experience. }\end{array}$ & 100 & 3.00 & .79 & 70 & 2.83 & .78 \\
\hline 9. & $\begin{array}{l}\text { I enjoy seeing how the infor- } \\
\text { mation learned in science class }\end{array}$ & 100 & 3.01 & .78 & 70 & 2.94 & .63 \\
\hline & can be used outside of school. & & & & & & \\
\hline & $\begin{array}{l}\text { I would like to be a scientist or } \\
\text { engineer. }\end{array}$ & 100 & 2.27 & .99 & 70 & 2.06 & .87 \\
\hline & $\begin{array}{l}\text { I often do science experiments } \\
\text { at home. }\end{array}$ & 100 & 2.02 & .82 & 70 & 2.16 & .92 \\
\hline & $\begin{array}{l}\text { School science clubs are a good } \\
\text { idea. }\end{array}$ & 100 & 2.43 & .78 & 70 & 2.26 & .74 \\
\hline & $\begin{array}{l}\text { I would like to be given a } \\
\text { science kit as a present. }\end{array}$ & 100 & 2.07 & .88 & 70 & 2.03 & .88 \\
\hline & $\begin{array}{l}\text { I like science more than any } \\
\text { other school work. }\end{array}$ & 100 & 2.30 & .91 & 70 & 2.11 & .89 \\
\hline & $\begin{array}{l}\text { I like to watch science } \\
\text { programs on } \mathrm{TV} \text {. }\end{array}$ & 100 & 2.34 & 1.00 & 70 & 2.27 & .91 \\
\hline & $\begin{array}{l}\text { I am always reading science } \\
\text { stories. }\end{array}$ & 100 & 1.84 & .75 & 70 & 1.73 & .67 \\
\hline & $\begin{array}{l}\text { One day I would like to go to } \\
\text { the moon. }\end{array}$ & 100 & 3.10 & 1.13 & 70 & 2.86 & .90 \\
\hline Ave & rage & & 2.44 & .88 & & 2.32 & .82 \\
\hline
\end{tabular}




\section{Pre- and Postsurvey Attitude Towards Science Data for Students in Inquiry- based Curriculum}

Data was collected in the presurvey and postsurvey that permitted capture of any changes in attitudes towards science resulting from the combination of the astronomy lessons and the Challenger Learning Center field trip by inquiry-based curriculum students.

Data. The results of students' attitude towards science between the presurvey and postsurvey for students in the inquiry-based curriculum are shown in Table 13. Raw data used to produce this table can be found in Appendix I. Notice all the scores increased from the presurvey to the postsurvey except for statement 12 "School science clubs are a good idea." The difference between the pre- and postsurvey mean score for statement 12 is not large but does show that students' attitude did decrease in this area after the astronomy lessons and the Challenger Learning Center field trip.

Effect Size. The aggregate effect size for students' attitudes towards science between the pre and post survey data for inquiry-based learners shown above in Table 13 is 0.10 . 
Table 13. Presurvey and postsurvey statements assessing attitude towards science of the students in the inquiry-based curriculum*.

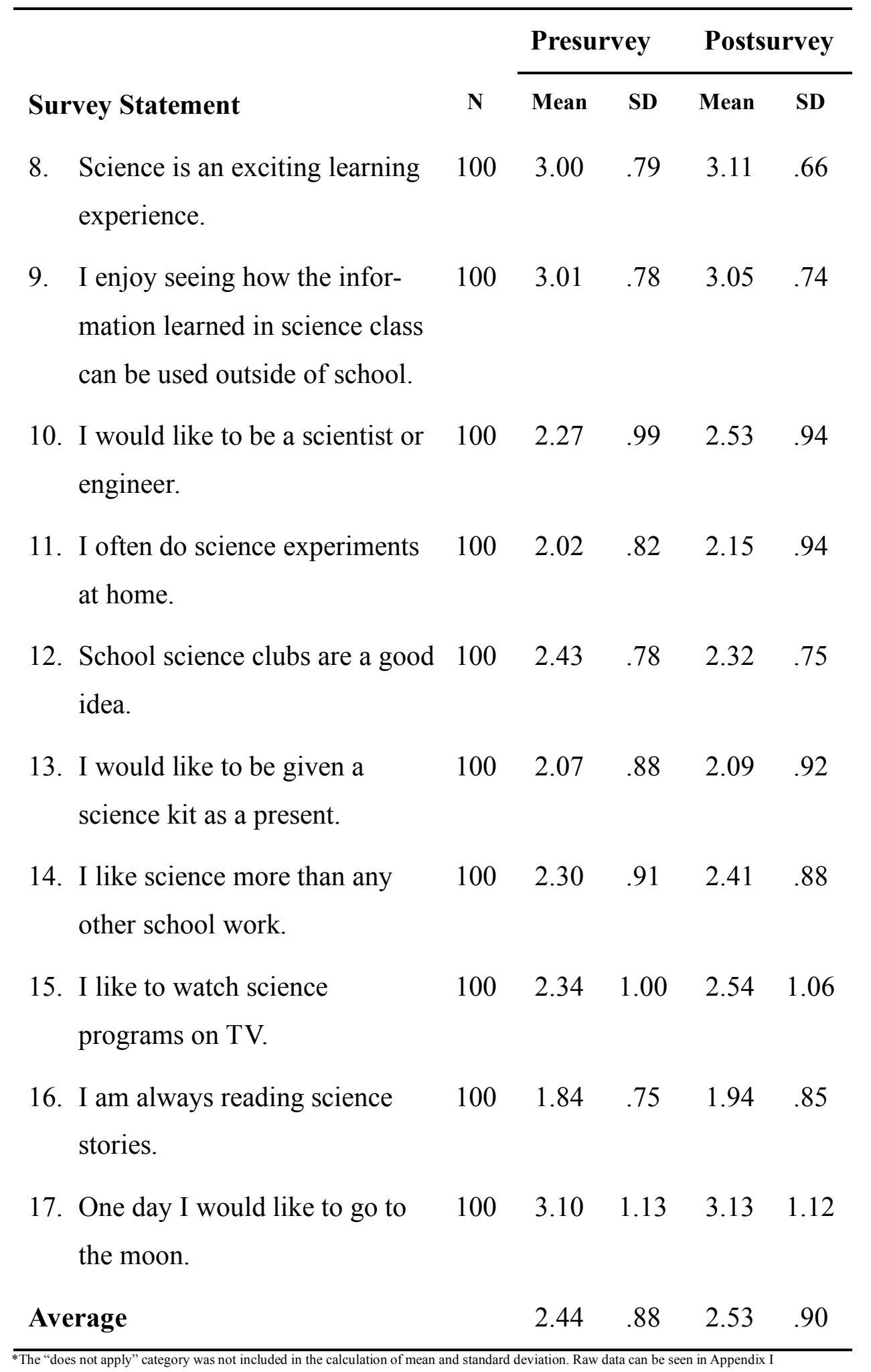




\section{Pre- and Postsurvey Attitude Towards Science Data for Students in Traditionally-based Curriculum}

Data was collected in the pre- and postsurvey that permitted capture of any changes in attitudes towards science resulting from the combination of the astronomy lessons and the Challenger Learning Center field trip by traditionally-based curriculum students.

Data. The results of attitude towards science between the pre- and postsurvey among the traditionally-based learners are shown in Table 14. Raw data used to produce these tables can be found in Appendix J. Notice all the scores increased from the presurvey to the postsurvey except for statement 9 "I enjoy seeing how the information learned in science class can be used outside of school." The difference between the pre- and postsurvey mean scores for this statement is important and does show that students' attitude did decrease in this area after the astronomy lessons and the Challenger Learning Center field trip.

Effect Size. The aggregate effect size for students' attitude towards science between the pre- and postsurvey data for inquiry-based learners in Table 14 is 0.17 . 
Table 14. Pre- and postsurvey statements assessing attitude towards science of the students in the traditionally-based curriculum*.

\begin{tabular}{|c|c|c|c|c|c|}
\hline \multirow[b]{2}{*}{ Survey Statement } & \multirow[b]{2}{*}{$\mathbf{N}$} & \multicolumn{2}{|c|}{ PreSurvey } & \multicolumn{2}{|c|}{ PostSurvey } \\
\hline & & Mean & SD & Mean & SD \\
\hline $\begin{array}{l}\text { 8. Science is an exciting learning } \\
\text { experience. }\end{array}$ & 70 & 2.83 & .78 & 2.87 & .83 \\
\hline $\begin{array}{l}\text { 9. I enjoy seeing how the infor- } \\
\text { mation learned in science class }\end{array}$ & 70 & 2.94 & .63 & 2.75 & .71 \\
\hline can be used outside of school. & & & & & \\
\hline $\begin{array}{l}\text { 10. I would like to be a scientist or } \\
\text { engineer. }\end{array}$ & 70 & 2.06 & .87 & 2.37 & .93 \\
\hline $\begin{array}{l}\text { 11. I often do science experiments } \\
\text { at home. }\end{array}$ & 70 & 2.16 & .92 & 2.30 & .92 \\
\hline $\begin{array}{l}\text { 12. School science clubs are a good } \\
\text { idea. }\end{array}$ & 70 & 2.26 & .74 & 2.45 & .85 \\
\hline $\begin{array}{l}\text { 13. I would like to be given a } \\
\text { science kit as a present. }\end{array}$ & 70 & 2.03 & .88 & 2.27 & .97 \\
\hline $\begin{array}{l}\text { 14. I like science more than any } \\
\text { other school work. }\end{array}$ & 70 & 2.11 & .89 & 2.30 & .98 \\
\hline $\begin{array}{l}\text { 15. I like to watch science } \\
\text { programs on TV. }\end{array}$ & 70 & 2.27 & .91 & 2.45 & .89 \\
\hline $\begin{array}{l}\text { 16. I am always reading science } \\
\text { stories. }\end{array}$ & 70 & 1.73 & .67 & 1.97 & .83 \\
\hline $\begin{array}{l}\text { 17. One day I would like to go to } \\
\text { the moon. }\end{array}$ & 70 & 2.86 & .90 & 2.94 & 1.01 \\
\hline Average & & 2.32 & .82 & 2.47 & .89 \\
\hline
\end{tabular}




\section{Postsurvey Attitude Towards Science of Students in Inquiry-based and Traditionally-based Curricula}

The final data for attitude towards science that was collected in the postsurvey allowed the contrast between the inquiry-based curriculum students and the traditionally-based curriculum students.

Data. This data was used to determine the difference in attitude towards science. The results of the postsurvey are shown in Table 15. Raw data used to produce these tables can be found in Appendix K.

Effect Size. The aggregate effect size for students' attitude towards science between postsurvey data for inquiry-based curriculum and traditionally-based curriculum shown in Table 15 is 0.07 . 


\section{Table 15. Postsurvey statements assessing attitude towards science of the inquiry-based and traditionally-based curriculum students*.}

\begin{tabular}{|c|c|c|c|c|c|c|}
\hline \multirow[b]{2}{*}{ Survey Statement } & \multicolumn{3}{|c|}{ Inquiry } & \multicolumn{3}{|c|}{ Traditional } \\
\hline & $\mathbf{N}$ & Mean & SD & $\mathbf{N}$ & Mean & SD \\
\hline $\begin{array}{l}\text { 8. Science is an exciting learning } \\
\text { experience. }\end{array}$ & 100 & 3.11 & .66 & 70 & 2.87 & .83 \\
\hline $\begin{array}{l}\text { 9. I enjoy seeing how the infor- } \\
\text { mation learned in science class }\end{array}$ & 100 & 3.05 & .74 & 70 & 2.75 & .71 \\
\hline can be used outside of school. & & & & & & \\
\hline $\begin{array}{l}\text { 10. I would like to be a scientist or } \\
\text { engineer. }\end{array}$ & 100 & 2.53 & .94 & 70 & 2.37 & .93 \\
\hline $\begin{array}{l}\text { 11. I often do science experiments } \\
\text { at home. }\end{array}$ & 100 & 2.15 & .94 & 70 & 2.30 & .92 \\
\hline $\begin{array}{l}\text { 12. School science clubs are a good } \\
\text { idea. }\end{array}$ & 100 & 2.32 & .75 & 70 & 2.45 & .85 \\
\hline $\begin{array}{l}\text { 13. I would like to be given a } \\
\text { science kit as a present. }\end{array}$ & 100 & 2.09 & .92 & 70 & 2.27 & .97 \\
\hline $\begin{array}{l}\text { 14. I like science more than any } \\
\text { other school work. }\end{array}$ & 100 & 2.41 & .88 & 70 & 2.30 & .98 \\
\hline $\begin{array}{l}\text { 15. I like to watch science } \\
\text { programs on TV. }\end{array}$ & 100 & 2.54 & 1.06 & 70 & 2.45 & .89 \\
\hline $\begin{array}{l}\text { 16. I am always reading science } \\
\text { stories. }\end{array}$ & 100 & 1.94 & .85 & 70 & 1.97 & .83 \\
\hline $\begin{array}{l}\text { 17. One day I would like to go to } \\
\text { the moon. }\end{array}$ & 100 & 3.13 & 1.12 & 70 & 2.94 & 1.01 \\
\hline Average & & 2.53 & .89 & & 2.47 & .89 \\
\hline
\end{tabular}


(This page deliberately blank) 


\section{Chapter 5 - Conclusion}

I wanted to see if students' learning preferences and attitude toward science were enhanced by using an inquiry-based curriculum and an experiential-based field trip to the Challenger Learning Center. The research demonstrated that using an inquiry approach to the curriculum has a somewhat positive effect on students' attitude toward science. The data also shows that students' attitude toward science in both groups of learners improved after the field trip to the Challenger Learning Center. The research also demonstrated that students in both learner groups preferred to learn through hands-on activities

\section{Analysis of Findings on Student Learning Preferences}

Data collected from student surveys revealed answers to the first section of research questions pertaining to learning preferences: Do students learning preferences differ depending upon the type of science curriculum they are taught or as a result of completing an experiential-based field trip? Four sub-questions resulted from this general question and were answered through administration of the survey to the students participating in the two different curricula before and after the experiential-based field trip to the Challenger Learning Center.

Is there a difference in the learning preferences between students in inquiry-based and traditionally-based curriculum before the astronomy lessons and the field trip to the Challenger Learning Center? The first question asked included both variable groups, inquiry and traditional learners. On the whole, the inquiry learners scored higher on five of the seven statements in the presurvey, which made the mean score higher for the inquiry learners. The data shows there is not a sizeable difference between the average mean for the inquiry learners at 2.70 and the traditional learners at 2.68. The aggregate effect size at .03 can be interpreted as a chance occurrence and not a real difference.

The first three statements on the survey include methods in which students prefer to learn. The data in Table 8 reveals that both learner groups prefer to learn through handson activities. Also data shows that students who were taught throughout the year using 
traditional methods of teaching have a stronger interest for "I learn best when I read a book or find information on my own" when compared to the inquiry learners interest level. I would infer that seventh grade science students who were taught with traditional methods feel more comfortable learning this way because it is the only way they have been taught. The least interest for inquiry learners was "I learn best when I read a book or find information on my own." Because inquiry students had not been taught with this method during their seventh grade year, it makes sense this was their least preferred method of learning. Inquiry learners largely preferred to learn through hands-on activities over the other two methods of learning given that hands-on activities were used throughout the school year to teach the inquiry group of students.

The foundation of inquiry learning is students asking questions and discovering different methods to answer their questions. Students who participated in this study took the presurvey in April, which means that the methods of teaching prior to the survey had an effect on students' presurvey responses. Data shows that the inquiry learners had a stronger interest than traditional learners in statements 4 and 7 . These statements refer to teachers asking questions and students having more questions as a result of their learning. The effect size for statement 4 is .23 and for statement 7 is .08. Both effect sizes signify a small deviation from the mean score, showing this data is reasonably accurate. Due to the methods in which students had been taught previous to the presurvey, the data results provide evidence that there is a difference in the way students prefer to learn. Is there a difference in learning preferences for students in an inquiry-based curriculum after the astronomy lessons and the field trip to the Challenger Learning Center? Mean scores for all statements increased except for statement 3, which had a minimal decrease (presurvey 3.58, postsurvey 3.57). Effect size for this statement was .02, which indicates the astronomy unit and field trip effect on the inquiry learner group was a best, chance. Table 9 shows the statement with the largest increase in mean score was statement 6 "I would consider a career in science or engineering." This increase might be due to the way the mission at the Challenger Learning Center is designed. Each student used science content and skills learned in the classroom to effectively complete tasks for the success of the mission. This experience gave students the opportunity to develop unique solutions to real problems by utilizing science and mathematical concepts, initiating independent 
research, and connecting directly with experts in the field. This feeling of success gave individual students a sense of accomplishment, which built excitement in students resulting, and in more students having the desire to seek a career in science or the engineering fields.

My data provides evidence that the cause for the increase in learning preference scores has to do primarily with the field trip to the Challenger Learning Center. The inquirybased learner group had been taught all year using inquiry methods within the classroom. The major difference in this unit of study compared to the other units studied during the school year was the field trip students participated in.

\section{Is there a difference in learning preferences students in a traditionally-based curriculum after the astronomy lessons and the field trip to the Challenger} Learning Center? Table 10 shows that overall traditional learners' aggregate scores did increase from the presurvey, 2.77 mean score, to the postsurvey, 2.81 mean score. All statements except for 1 and 5 increased in mean value. Statement 1 "I learn best when I read a book or find information on my own" decreased from 2.77 to 2.61 after the astronomy unit and the field trip to the Challenger Learning Center. Once again traditional students had been taught using similar methods throughout the school year. The key difference for these learners was the field trip to the Challenger Learning Center. This data hints that after traditional learners experienced the field trip their interest in participating in science activities instead of reading about science was greater than before.

Another change that occurred between the presurvey and postsurvey data on Table 10 was statement 6 "I would consider a career in science or engineering." The field trip had the same effect on traditional learners as it did on inquiry learners. Students became more interested in seeking careers in science and engineering after they were able to put to use the science content and skills they were taught in the classroom.

Finally, statement 7 was intended to focus on inquiry learning. In inquiry learning students are expected to develop questions from information learned in other lessons. For 
traditional learners the mean score showed a notable increase given that the curriculum did not focus on having them ask questions but instead had students answer another person's questions. One of the goals of the Challenger Learning Center is to help students pose questions and find pathways to answers. The postsurvey data confirms that the field trip did show a positive outcome in its aim to have students accomplish this goal. Is there a difference in the learning preferences of students in inquiry-based and traditionallybased curriculum after the astronomy lessons and the field trip to the Challenger Learning Center? Presurvey data between inquiry learners and traditional learners established a difference in learning preference. When looking at the postsurvey data, once again the inquiry-based learners had a stronger interest than the traditional learners. Both learner groups overall average mean scores did increase, inquiry learners from 2.70 to 2.82 and traditional learners from 2.68 to 2.75 . This shows that the astronomy curriculum and the field trip did result in a positive effect on students' learning preferences.

After students completed the astronomy lessons and the experiential field trip, the inquiry-based learners showed trivial differences between their pre and post surveys, though traditional-based learners had a greater variation of scores between the two surveys. Table 11 shows inquiry learners' scores increased in their preference to learn through reading and finding information on their own, whereas traditional learners' scores decreased for this statement. Although a few of the traditional learners' scores did decrease, it was not a big enough decrease in mean score to change their agreement of the statements from disagree to agree. Once again, since students had been taught using a similar curriculum throughout the school year the main difference for this unit was the field trip to the Challenger Learning Center.

Finally, students' scores show that they do prefer teachers asking questions instead of giving answers. These scores were slightly lower for both learner groups after the curriculum and the experiential field trip but not enough to provide evidence that the two variables had changed students' attitudes about this statement. Although students were taught using different curricula, this data provides evidence that student learning preference did not always conform to the method in which they were being taught. 


\section{Do students learning preferences differ depending upon the type of science}

curriculum they are taught or as a result of completing an experiential-based field trip? Data from the four sub-questions revealed that the way students were taught did not have an influence on the dominant learning preference. Both groups of learners' dominant learning preference, before and after the astronomy curriculum and the field trip to the Challenger Learning Center, was hands-on activities. Data from Tables 8-11 show that mean scores were very similar for both the pre- and post-surveys for both learner groups, showing that no change occurred in learning preference because of the curriculum or the field trip.

The Challenger Learning Center is an experiential-based environment in which students are actively engaged in hands-on research and solving problems. Because students preferred to learn through hands-on activities before the field trip, the experience apparently had no affect on their learning preferences.

\section{Analysis of Findings on Students' Attitudes Towards Science}

The second general question concerns students' attitude toward science, which are influenced by interest in science outside of the classroom: Do student attitudes towards science change depending upon the type of science curriculum they are taught or as a result of completing a experiential-based field trip? Four sub-questions resulted from this general question and can be answered through administration of the survey to the students participating in the two different curricula before and after the experiential-based field trip to the Challenger Learning Center.

\section{Do attitudes towards science differ between students in an inquiry-based and} traditionally-based curriculum before the astronomy lessons and the field trip to the Challenger Learning Center? Presurvey data in Table 12 shows the overall attitude of inquiry learners towards science is slightly higher than traditional learners. The average mean score for inquiry learners is 2.44 and for traditional learners is 2.32 . The aggregate effect size for the two learner groups' presurvey is 0.13 , which shows that there is a difference of small importance between these two learner groups. Inquiry learners 
had higher mean scores than traditional learners on nine of the ten statements assessing students' attitude toward science. Statements 8, 10, 11, 12, 14, 16, and 17 all had an effect size over 0.10 , which means that there was a difference of small importance between the two groups. Statements 9, 13, and 15 all had effect sizes smaller than 0.10 , which means that there was a trivial difference between learners for these statements.

Students in both learner groups had low average means for statements that focused on their involvement in science out of the classroom such as "I often do science experiments at home" to "I am always reading science stories." While statements that dealt with enjoyment of science such as "Science is an exciting learning experience" and "I enjoy seeing how the information learned in science class can be used outside of school" had higher average mean scores.

\section{Is there a change in attitude towards science in inquiry-based curriculum students after the astronomy lessons and the field trip to the Challenger Learning Center?}

Data in Table 13 shows that the average mean scores for all statements that assessed attitude increased except for statement 12 "School science clubs are a good idea." Overall this increase in mean scores showed a minimal difference between the presurvey and postsurvey. Statements 9, 13, and 17 had very small differences with their effect size being lower than 0.10. All other statements had effect sizes between 0.11 and 0.30 . This shows that learning using an inquiry curriculum and the field trip to the Challenger Learning Center had a small effect on students' attitude toward science. Because students were taught using inquiry methods throughout the school year, the astronomy unit apparently did not have much of an effect on attitudes and the key difference was the field trip to the Challenger Learning Center.

The statement "I would like to be a scientist or engineer" had one of the largest increases from the presurvey to the postsurvey. Students' average mean scores went from 2.27 to 2.53 with an effect size of 0.27 . This change possibly occurred because students were given the opportunity to act as scientists and engineers during the field trip. Most students in seventh grade had never had an experience like the one at the Challenger Learning Center. When students observed science content used outside of the classroom their interest in pursuing science as a career increased. 
Is there a change in attitude towards science in traditionally-based curriculum students after the astronomy lessons and the field trip to the Challenger Learning

Center? Average mean scores for traditional learners between presurvey and postsurvey, shown in Table 14, did increase. Statements 8 and 17 had an effect size smaller than 0.10 , which could be considered chance. Statements 10 and 16 showed differencing moderate importance in students' attitude with their effect size being greater than 0.30 . The rest of the statements show that the astronomy lessons and field trip only slightly affected the students' attitude.

The field trip to the Challenger Learning Center seemed to have the biggest impact on students' attitude, which could possibly affect students' career choices. I do not believe the astronomy unit had an impact on the postsurvey because students had been taught with the same methods before the presurvey was given. The statement "I would like to be a scientist or engineer" had the largest increase compared to any other statement assessing students' attitude.

Another notable change in the data showed that traditional learners' mean scores increased and had a small effect on statements pertaining to students' likes, such as "I like to watch science programs" and "I like science more than any other schoolwork." This possibly shows students' attitudes are beginning to change. For a more permanent change to take place, more experiential field trips would be needed in students' science careers.

\section{Do attitudes towards science in an inquiry-based and traditionally-based} curriculum differ after the astronomy lessons and the field trip to the Challenger Learning Center? After comparing postsurvey scores, the overall data showed there was a minimal change between the two learner groups. The aggregate effect size between the two learner groups was 0.07 . Yet for specific statements larger differences did occur.

Statement 8 of Table 15 "Science is an exciting learning experience" showed a notable difference in which inquiry learners had greater interest than traditional students. The effect size for this statement is 0.32 , which shows there is a difference of moderate 
importance between the two groups. Also, the results of statement 9 "I enjoy seeing how the information learned in science class can be used outside of school" also showed a difference of moderate importance between the learner groups. The effect size for this question is 0.41 , which is the largest effect size of the study.

After the field trip to the Challenger Learning Center, it seems that inquiry-based learners' attitude ratings increased compared to the traditional learners. This data shows that there is a difference between inquiry learners and traditional learners and the way they prefer to see science outside the classroom. This difference is more noticeable within individual survey statements.

\section{Do student attitudes towards science differ depending upon the type of science curriculum they are taught or as a result of completing an experiential-based field} trip? After analyzing the presurvey and postsurvey data in Tables 12-15, it is apparent that an overall change in attitude occurred, but it was a small change for both inquiry learners and traditional learners. It is also clear that different aspects, shown by specific statements, of attitude toward science changed in a positive manner. It is my belief that the change in attitude could have been caused by the field trip to the Challenger Learning Center. Prior to the presurvey, students were taught using the same methods as they had been using throughout the school year. Thus the most significant event that occurred prior to the postsurvey was the field trip to the Challenger Learning Center.

Statements on the survey showed specific changes in attitudes toward science. The most significant change for both the inquiry learners and traditional learners was statement 10 "I would like to be a scientist or engineer." As a science teacher, I feel this could be one of the most important attitude changes in the data because it showed that students enjoyed science enough to pursue it as a career. After seeing this data, I feel it would be extremely beneficial for students to participate in an experiential-based field trip each year. The interactive problem solving methods used in experiential-based field trips could have a large impact on students choosing science as a career. 


\section{Related Results}

The results of my research are similar to that of researchers Jarvis and Pell. Their research included 655 students who attended the Challenger Learning Center in the United Kingdom. Jarvis and Pell's attitude survey was given just before going to the Challenger Learning Center and the postsurvey was given within three days of the field trip. Also, Jarvis and Pell did two follow up surveys, two and five months, after their visit to the Challenger Learning Center. They found in the posttest given three days after the field trip, the biggest increase in attitude was with students' aspirations to be scientists (Jarvis \& Pell, 2002). These finding are equivalent to the findings in my research. The statement "I would like to be a scientist or engineer" had the largest increase, for both learner groups, compared to any other statement assessing students' attitude. Other statements pertaining to attitudes in Jarvis and Pell's survey increased, but not by any notable amount.

One goal of the Challenger Learning Center is to excite today's youth about the wonders of space and the adventures of a career in science, technology, engineering and mathematics. The most significant event that occurred between administering the presurvey and the postsurvey was the field trip to the Challenger Learning Center. My research findings support this goal. Student's interest in seeking a career as a scientist or engineer increased due to the field trip. This is not surprising due to the engaging nature of the Challenger Learning Center; students are excited to see science in action.

\section{My Personal Observation}

My personal observation made after the field trip to the Challenger Learning Center, was that students were very excited to have completed "Rendezvous with a Comet" successfully. As we boarded the bus, students were talking about exciting occurrences during the mission: oxygen emergency, the completion of the probe, the launching of the probe, and a safe landing. The ten minute bus ride was filled with laughter and reliving the comet mission. When we returned to the classroom, students were given time to answer and discuss debriefing questions about the mission. Once again, students continued to talk about the fun they had on the field trip. 


\section{Implications}

After identifying students learning preferences, data from this research will be used when planning classroom curriculum. Seeing that students prefer to learn through hands-on activities motivates me as a teacher to provide these types of lessons for students. But it is not always possible for students to do hands-on activities, so the data is helpful to see that students also prefer to learn by listening to someone talk to them.

It is my goal, as well as a goal of the science department at Mountain Ridge Middle Schools, to implement inquiry curriculum into science classrooms as often as possible. Statements 4, 5 and 7 in the survey all relate to inquiry methods in teaching and are helpful when planning how to present content to students. For example, doing a demonstration for students that will encourage them to ask their own questions, which in turn will eventually lead students into their own personal investigation.

Experiential based field trips provide students the opportunity to give abstract science concepts concrete meaning. In addition, students develop realistic processes of cooperation, communication, critical thinking, and problem solving. After discovering this I have developed another experiential field trip in which students will be collecting data from four different ecosystems in the Colorado Springs region. Teaching students to think like scientists and giving them the opportunity to act like scientists outside the classroom should be the main objective of experiential education.

Mountain Ridge Middle school invests five thousand dollars a year to send students to the Challenger Learning Center, this research affirms that money is being spent effectively for the enhancement of the science curriculum and could be added to all levels of students' science education within the district. This research will also be useful for curriculum directors, science museums and educational centers as they design curriculum to effectively teach students science content. While science education looks for new ways of reaching students, experiential education might just be the most effective answer. 


\section{Changes for Future Research}

When finishing the research study I realized there were numerous conditions I would change if I was to do this again or if I were to further my research. One change I would like to see is the study being done at the beginning of the school year compared to the end of the school year. By giving the survey at the beginning of the school year, students learning preferences and attitudes would not been influenced by any outside variables from the present school year. Also I would have one teacher teach both the inquiry and traditional curriculum to different classes. These changes would lead to a more standardized experiment.

In addition to these changes I would further the research by partaking in a longitudinal study, similar to researchers Jarvis and Pell. In their research they gave postsurvey within three days after the Challenger Learning Experience, and then followed up with surveys two and five months later (Jarvis \& Pell, 2002). By doing a longitudinal study the researcher is able to see if the Challenger Learning experience has a lasting affect on students' attitude. Often times an immediate response to survey statements is based on emotion rather than realistic feelings. By giving the survey two and five months later the researcher is able to see a more accurate effect from the experiential trip. 
(This page deliberately blank) 


\section{References}

A.E.E. Association for Experiential Education's what is experiential education?

Retrieved August 15, 2006, from

http://www.aee.org/customer/pages.php?pageid=47

Bracey, G. W. (2000). Differentiate Practical and Statistical significance. Bail Me Out:

Handling Difficult Data and Tough Questions about Public Schools (pp. 58-62).

Thousand Oaks, CA: Corwin Press.

Challenger Center for Space Science Education. (2001). Mission Prep, A Teacher's Activity Guide [Brochure]. Author.

Colburn, A. (2004). Inquiring Scientists Want to Know. Educational Leadership, 62, 6366.

Crosby, A. (1981). A Critical Look: The Philosophical Foundations of Experiential Education. Journal of Experiential Education, 4, 9-15.

Dewey, J. (1938). Experience and Education (pp. 54-72). New York: Macmillan.

Gonzales, P., Guzman, J. C., \& Partelow, L. (2004). Highlights From The Trends In International Mathematics And Science Study (TIMSS) 2003 (Rep.). Washington DC: NCES.

Horton, R. L., \& Hutchinson, S. Nurturing Scientific Literacy Among Youth Through Experientially Based Curriculum Materials. Retrieved March, 2006, from http://www.ag.ohio-state.edu/ youth4h/expedu/ 
International Baccalaureate Organization (2000). International Baccalaureate Organization Middle Year Programme Implementation and Development of the Programme. (2000). Geneva, Switzerland: International Baccalaureate Organization.

Jarvis, T., \& Pell, A. (2002). Effect of the Challenger Experience on Elementary Children's Attitudes to Science. Journal of Research in Science Teaching, 39, 9791000. Retrieved May 13, 2006, from Wiley Periodicals database.

Jarvis, T., \& Pell, A. (2005). Factors Influencing Elementary School Children's Attitudes Toward Science Before, During, and After a Visit to the UK National Space Center. Journal of Research in Science Teaching, 42, 53-83. Retrieved February, 2006, from Wiley Periodicals database.

Lederman, N. G. (1998). The State of Science Education: Subject Matter Without Context. Electronic Journal of Science Education [On-line], 3, Http://unr.edu/homepage/jcannon/ejse/lederman.html.

Mattheis, F. E., \& Nakayama, G. (1988). Effects of a Laboratory-Centered Inquiry Program on Laboratory Skills, Science Process Skills, and Understanding of Science Knowledge in Middle Grades Students. Retrieved January, 2006, from ERIC Document Reproduction Services ED307148 database.

Meyers, R. E., \& Fouts, J. T. (1992). A cluster analysis of high school science classroom environments and attitudes toward science. Journal of Research in Science Teaching, 29, 929-938. 
National Education Goals Panel. (1992). National Education Goals Report: Building a Nation of Learners. Washington DC, US: Government Printing Office.

National Research Council. (2000). Inquiry and the National Science Education Standards. Washington: National Academy Press.

Piburn, M., Sidlik, L. P., \& Mulvenon, S. (1992). An Investigation of Projective Measures of Attitude Toward Science (Rep.). Tempe, Arizona: College of Education Arizona State University. (ERIC Document Reproduction Service No. ED361 219)

Rennie, L., \& McClafferty, T. (1995). Using Visits to Interactive Science and Technology Centers, Museums, Aquaria and Zoos To Promote Learning in Science. Journal of Science Teacher Education, 6, 175-185.

Shaver, J.P. (1985). Chance and nonsense: A conversation about interpreting tests of statistical significance, part 1. Phi Delta Kappan, 67, 57-60.

Shrigley, R. L. (1990). Attitude and Behavior Are Correlates. Journal of Research in Science Teaching, 27, 97-113. 
(This page deliberately blank) 
Appendix A

Learning Preference and Attitude Towards Science Survey Form 
(This page deliberately blank) 
Student Statistics: Male Female Team

\section{Science Survey}

Please circle a response that most fits your level of agreement with each of the following statements.

1. I learn best when I read a book or find information on my own.

Strongly disagree

disagree

agree

strongly does not agree apply

2. I learn best when I listen to someone talk about the topic I am trying to learn.

Strongly disagree

3. I learn best when I do hands on activities.

Strongly disagree

(n)

(n)

does not

4. I like it when teachers ask questions instead of giving me answers.

5. I like discovering information on my own.

\begin{tabular}{|c|c|c|c|c|}
\hline $\begin{array}{l}\text { Strongly } \\
\text { disagree }\end{array}$ & disagree & agree & $\begin{array}{c}\text { strongly } \\
\text { agree }\end{array}$ & $\begin{array}{c}\text { does not } \\
\text { apply }\end{array}$ \\
\hline
\end{tabular}

6.

\begin{tabular}{|c|c|c|c|c|c|c|}
\hline 6. & $\begin{array}{l}\text { I would consider a career in science or } \\
\text { engineering. }\end{array}$ & $\begin{array}{l}\text { Strongly } \\
\text { disagree }\end{array}$ & disagree & agree & $\begin{array}{l}\text { strongly } \\
\text { agree }\end{array}$ & $\begin{array}{l}\text { does not } \\
\text { apply }\end{array}$ \\
\hline 7. & $\begin{array}{l}\text { I find that I have more questions as a result of my } \\
\text { learning. }\end{array}$ & $\begin{array}{l}\text { Strongly } \\
\text { disagree }\end{array}$ & disagree & agree & $\begin{array}{l}\text { strongly } \\
\text { agree }\end{array}$ & $\begin{array}{l}\text { does not } \\
\text { apply }\end{array}$ \\
\hline 8. & Science is an exciting learning experience. & $\begin{array}{l}\text { Strongly } \\
\text { disagree }\end{array}$ & disagree & agree & $\begin{array}{l}\text { strongly } \\
\text { agree }\end{array}$ & $\begin{array}{l}\text { does not } \\
\text { apply }\end{array}$ \\
\hline 9. & $\begin{array}{l}\text { I enjoy seeing how the information learned in } \\
\text { science class can be used outside of school. }\end{array}$ & $\begin{array}{l}\text { Strongly } \\
\text { disagree }\end{array}$ & disagree & agree & $\begin{array}{l}\text { strongly } \\
\text { agree }\end{array}$ & $\begin{array}{l}\text { does not } \\
\text { apply }\end{array}$ \\
\hline 10. & I would like to be a scientist or engineer. & $\begin{array}{l}\text { Strongly } \\
\text { disagree }\end{array}$ & disagree & agree & $\begin{array}{l}\text { strongly } \\
\text { agree }\end{array}$ & $\begin{array}{l}\text { does not } \\
\text { apply }\end{array}$ \\
\hline 11. & I often do science experiments at home. & $\begin{array}{l}\text { Strongly } \\
\text { disagree }\end{array}$ & disagree & agree & $\begin{array}{c}\text { strongly } \\
\text { agree }\end{array}$ & $\begin{array}{c}\text { does not } \\
\text { apply }\end{array}$ \\
\hline 12. & School science clubs are a good idea. & $\begin{array}{l}\text { Strongly } \\
\text { disagree }\end{array}$ & disagree & agree & $\begin{array}{c}\text { strongly } \\
\text { agree }\end{array}$ & $\begin{array}{c}\text { does not } \\
\text { apply }\end{array}$ \\
\hline 13. & I would like to be given a science kit as a present. & $\begin{array}{l}\text { Strongly } \\
\text { disagree }\end{array}$ & disagree & agree & $\begin{array}{c}\text { strongly } \\
\text { agree }\end{array}$ & $\begin{array}{c}\text { does not } \\
\text { apply }\end{array}$ \\
\hline 14. & I like science more than any other school work. & $\begin{array}{l}\text { Strongly } \\
\text { disagree }\end{array}$ & disagree & agree & $\begin{array}{c}\text { strongly } \\
\text { agree }\end{array}$ & $\begin{array}{c}\text { does not } \\
\text { apply }\end{array}$ \\
\hline 15. & I like to watch science programs on $\mathrm{TV}$. & $\begin{array}{l}\text { Strongly } \\
\text { disagree }\end{array}$ & disagree & agree & $\begin{array}{c}\text { strongly } \\
\text { agree }\end{array}$ & $\begin{array}{c}\text { does not } \\
\text { apply }\end{array}$ \\
\hline 16. & I am always reading science stories. & $\begin{array}{l}\text { Strongly } \\
\text { disagree }\end{array}$ & disagree & agree & $\begin{array}{c}\text { strongly } \\
\text { agree }\end{array}$ & $\begin{array}{c}\text { does not } \\
\text { apply }\end{array}$ \\
\hline & One day I would like to go to the moon. & $\begin{array}{l}\text { Strongly } \\
\text { disagree }\end{array}$ & disagree & agree & $\begin{array}{l}\text { strongly } \\
\text { agree }\end{array}$ & $\begin{array}{c}\text { does not } \\
\text { apply }\end{array}$ \\
\hline
\end{tabular}


(This page deliberately blank) 


\section{APPENDIX B}

Inquiry Lesson Plans 
(This page deliberately blank) 


\section{Inquiry lesson plans}

The following activities include basic information on comets. Interestingly enough, not all scientists agree that this information is "the truth." Perhaps it is safer to say, these are common scientific theories about comets. Scientists often interpret the same data in different manners, developing theories based on these interpretations. The upcoming missions being conducted by NASA will provide new information, possibly changing the "facts" and theories presented in these activities.

\section{Activity One}

\section{The Difference between Comets, Meteors and Asteroids}

\section{Key Questions}

The teacher will begin with focus questions:

1. Do you know the difference between comets and meteors?

2. Did you know that comets travel across the sky very slowly?

3. Do you know where comets, asteroids, and meteors come from?

\section{Objectives:}

Students will be able to analyze and identify a list of characteristics pertaining to comets, meteors, and asteroids.

\section{Introduction}

The teacher should ask students what they know about comets, meteors, and asteroids. After leading a classroom discussion on their prior knowledge the teacher should show

The teacher will then show the Introduction to Comets, Meteors and Asteroids Movie (http://neo.jpl.nasa.gov/images/coolcomets.html.).

After the movie has finished distribute and explain the worksheets to the students.

\section{Hands-on Activity}


Students are to use the list of characteristics at the bottom of the worksheet to fill in the Venn diagram. Students will work independently to fill in the diagram. Students will also need to include a short paragraph explaining the similarities and differences between comets, meteors and asteroids. Students must be able to justify and explain why they placed the characteristics in the different parts of the diagram.

\section{Check for Understanding}

The teacher will circulate through the classroom monitoring student's progress. Once all students have had the opportunity to complete the diagram, begin the closure activity.

\section{Closure:}

As a closure activity, the teacher will review the diagram with the students. The teacher should make an overhead image of the diagram to fill in eliciting feedback from the students. Once completed, the teacher should summarize the characteristics displayed in the diagram.

\section{References}

Imperial Oil National Center For Mathematics, Scie. Ninth Grade Astronomy Curriculum Resources. Retrieved March/April, 2006, from

http://www.ioncmaste.ca/homepage/resources/web_resources/CSA_Astro9/files/html/mo dule5/lessons/lesson2/diff_CMA.html.

National Aeronautics and Space Administration. Retrieved March/April, 2006, from http://neo.jpl.nasa.gov/images/coolcomets.html. 


\section{Activity Two}

\section{Cookin' Up a Comet}

\section{Key Question}

What are comets made of?

\section{Objective}

Compare the parts of the model to the parts of a comet.

\section{Preparation}

1. Purchase dry ice from ice companies or ice cream parlors the afternoon or evening prior to the demonstration. If possible, get the pellet form of dry ice. Be sure to purchase at least five pounds of dry ice. You will want to get enough extra for a test run at home the night before.

2. Store the dry ice in an ice chest. Place an inch or so of newspaper between the dry ice and the container to prevent the container from cracking.

3. Conduct this activity before using it in the classroom to get a feel for the correct amount of water to use.

CAUTION! Dry ice is $-79^{\circ} \mathrm{C}\left(-110^{\circ} \mathrm{F}\right)$. Any more than brief exposure to the skin will cause "burns." Everyone handling dry ice should wear heavy, rubber gloves! Be sure to discuss safety precautions with students when working with dry ice.

\section{Timeline}

1 class

\section{Materials}

$5 \mathrm{lbs}(\sim 2 \mathrm{~kg})$ dry ice pellets or

block, chopped finely

3 cups of water

A few drops of ammonia

A handful of sand or ground charcoal

A can of soda (cola)

A large wide mixing bowl

and plastic

wrap

\section{Management}

This comet recipe is fun to do. It is also messy and one of the more scientifically accurate demonstrations in astronomy.
A hammer

A large wooden or plastic spoon for stirring A large plastic tub Heavy, rubber gloves Protective eye goggles (1 per students) Cloth or paper towels Optional: Overhead Projector, hair dryer, 


\section{Procedure}

1. Put on heavy gloves before using a hammer to crush the dry ice pellets or block in the large plastic tub to the consistency of snow. Everyone should wear protective eye goggles.

2. Pour $18 \mathrm{oz}$ ( 2.5 cups) of water into the mixing bowl. Add a handful of sand, a little ammonia, and the cola, mixing as you pour.

3. Add 2.5 cups of dry ice to the mixture. Stir carefully. Vapor will form as you stir, and the mixture will get slushy. Keep stirring for a few seconds while it thickens.

4. Use the mixing spoon to clean the slush away from the sides of the bowl into the bottom. Reach in and pack the slush into a ball. Keep packing and forming until you have a ball that forms a big lump. Add water to help the ice stick together. REMINDER: DO NOT HANDLE DRY ICE MIXTURE WITH BARE HANDS!

5. Sprinkle more sand over the comet. Pour some of the remaining water over the comet turning it as you do, so that a layer of water ice forms over the entire surface.

6. Observe the behavior of your miniature comet nucleus. Cool Comet Viewing Tip: So the whole class can watch the gas sublimating out of the comet, use an overhead projector. Be sure to protect the overhead projector by covering the glass with plastic wrap. CAUTION! Do not leave the comet on the projector long; the dry ice could damage it.

7. Blowing hard on the comet gives a sense of simulating a comet tail. One suggestion is to use a hair dryer set on a low setting.

8. Discuss the parts of a comet using the Comet Fact Sheet.

The ingredients used to "build" a comet represent our current understanding of the components found in actual comets: frozen water, frozen carbon dioxide and other frozen gases, dust and rock, and organic (carbon-based) substances.

Scientists have studied the spectrum of light coming from real comets' comas and tails to determine the presence of these substances.

As the comet in this experiment melts, you can see little jets of gas coming off the comet just like the observed "outgassing" of real comets, which can actually affect the movement of the comet. After further melting of the experimental comet, craters will begin to form, another characteristic of real comets.

9. Discuss the Reflection Questions as a class.

\section{Reflection Questions}

1. When you place the comet on the tray to observe it, what part of the comet does 
it represent?

2. Describe changes, if any, in the comet after 5 minutes have elapsed.

3. Use the hair dryer to represent the Sun and the solar wind. Set the dryer on the low setting and blow air on the comet. What part of the comet begins to form?

What happens when you move the hair dryer closer to the comet?

4. What components of real comets are represented by each of the ingredients in your comet? 


\section{Activity Three}

\section{Famous Comets}

\section{Overview}

Comets have played significant roles in both recent and ancient history. Usually considered

bad omens by our ancestors, comets have more recently sparked interest due to their beauty, uniqueness, and sometimes their dramatic fates. This lesson has students research some of the more notable comets using the Internet and give a report on their findings.

\section{Objectives}

Research and compare two comets and identify differences, such as eccentricity, perihelion, long term or short term comet, in the two comets.

\section{Preparation}

1. Copy enough Task sheets so students know what information they need to research.

2. Assign each student with a different comet to do research on.

3. Make arrangements for each team to have at least 1 hour of Internet access.

\section{Management}

Allow students plenty of time to research their comet. If necessary, encourage them to work on their project after-hours.

\section{Timeline}

1 class: Research on comet (Optional to do this in class or as homework.)

1 class: Have student compare and contrast different comets

\section{Key Question}

What are the differences among comets?

\section{Materials Needed}

Comet Research questions

Computers with access to the World Wide Web

Reference books/periodicals, etc.

Venn Diagram

\section{Procedures}

1. Review comets using the Comet Fact sheet. Discuss the anatomy, location, orbital paths, and composition of comets.

2. Assign students a comet to research (I give two students the same comet but will not let them work in partners; this is to verify the data they find.)

Halley

Arend-Roland

Encke

Kohoutek
Swift-Tuttle

Temple1

Hyakutake

Shoemaker Levy9 
Hale Bopp

D'Arrest

Tempel-Tuttle
Wild 2

Wilson-Harrington

Biela's Comet

3. Questions students should look up about their comets:

When was the comet discovered?

$>$ How long is this comets period?

$>$ Who discovered the comet and was this person a professional or amateur astronomer?

$>$ When did it reach its perihelion and or aphelion? (Look up words you don't know.)

$>$ What shape was its orbit?

What specific substance makes up this comet?

$>$ What is comets eccentricity?

4. Using the given Internet addresses and reference materials, have students answer the questions.

5. Once students have collected their research, students will get with a partner who had a different comet, compare and contrast their comets and complete a Venn Diagram.

6. After Venn Diagrams are complete, the teacher will lead a discussion on the differences in comets and have students explain terms such as short or long term comets, eccentricity, and perihelion. 


\section{Activity Four}

\section{Cometary Orbits}

\section{Overview:}

This activity introduces the geometrical concepts of an ellipse to students. It asks them to use mathematics to generate their own ellipses, and then use these ellipses as orbital models of planets and comets.

\section{Objectives:}

Students will:

-Create ellipses and use them as models of real orbits.

-Apply mathematics to determine properties of ellipses.

-Compare the orbits of planets and comets.

\section{Key Question:}

How are the orbits of comets different than the orbits of the planets?

How are the orbits of long period and short period comets different?

\section{Materials and Preparation:}

Each student will need:

- A student Worksheet entitled Cometary Orbits

- $25 \mathrm{~cm} \times 30 \mathrm{~cm}$ piece of cardboard

- 3 blank, white sheets of 8.5x11 paper

- pencil

- $20 \mathrm{~cm}$ long piece of string

- 2 push pins

- ruler

- tape

1. Review the students procedures, as listed on the Student Worksheet

2. Collect corrugated cardboard boxes and cut out pieces approximately $25 \mathrm{~cm} \mathrm{x}$ $30 \mathrm{~cm}$.

3. Before starting this lesson, students mush use knowledge from the "Famous Comet Research" lesson plan to have an understanding of the path that comets travel on, ellipses. Also teachers might want to review information from previous units on planets that all objects in the Solar System travel around the Sun in an ellipse. If possible, review diagrams on orbits of planets, asteroids and comets as an example.

4. Briefly demonstrate how to use the pencil, string and thumbtacks to draw an ellipsis. As a class, note the foci and major and minor axes of the ellipse.

5. Once the students activity is completed show this idea using the following web site: http://www.windows.ucar.edu/tour/link=/comets/comet_model_interactive.html -With an LCD projector connected to a computer show this website to your class. 
- Choose a student and ask for their data (eccentricity, and orbit size or perihelion) from their famous comet they researched the class before. Plug this information into the interactive website to show students how that specific comet would orbit the sun. 


\section{Activity Five}

\section{Investigating Falling Particles}

\section{Overview:}

Students will measure a clay ball, and then drop it from different heights to examine how the impact changes the clay ball. Through class discussions, students will relate this to capturing comet particles. Also students will brainstorm and explain their ideas of different mediums to capture cometary dust without changing the particles.

\section{Objectives:}

Students will:

-Investigate the characteristics of a clay ball.

-examine what happens to a ball of clay that is dropped from different heights.'

-Brainstorm various mediums to collect falling particles without changing the characteristics of the captured particles.

\section{Key Question:}

How might an impact of a fast-moving object change the characteristics of the object?

\section{Materials and Preparation}

- Paper towels or newspapers to cover the floor

- A golf ball size clay ball

- Students worksheet entitled Investigating Falling Particles

- Meter stick or tape measure

- Ruler

- Index cards

- Areogel power point presentation

1. Students will observe what and record what happens to the clay ball when it hits a hard surface at different heights.

2. Students will brainstorm some problems a moving spacecraft would have when trying to capture moving comet particles?

3. Students will then make a list of things you need to consider when collecting comet particles, keeping in mind that the spacecraft and the particles are both moving.

4. Finally, students will brainstorm with a group, five possible mediums (materials) that you could use as a particle collector. Once they have their mediums they will figure out which on is the best.

5. Once students have completed the investigation, show them the power point for Aerogel which is the actually medium that NASA uses to capture comet particles. 


\section{Investigating Falling Particles}

Often scientists have to be creative in order to accomplish their research. For example, how might you measure the size of something that is too small to be seen, life an atom, or extremely large, like the Sun? One problem posed to scientists a few years ago was: How can you collect fast moving dust particles without causing changes in their physical structure when they hit the collection device? As part of your mission at the Challenger Learning Center, you will want to collect particles from Comet Encke. You must think about how that will be collected. We want the particles to be in their original state so we can study them once they arrive on earth.

\section{Investigate how a particle falls.}

1. Using a clay ball, drop the all from 3 different heights. After each drop write detailed observations about the ball. (Record size changes, shape changes, etc.)

Drop 1-

Drop2-

Drop3-

2. What would be some (at least 3 ) of the problems with a moving spacecraft trying to capture moving comet particles?

3. Make a list of things (at least 5) you need to consider as you think about collecting comet particles. Keep in mind also that the spacecraft and the particles are both moving.

We need to figure out a way to catch come particles. Sounds easy but, these are the conditions that we have to deal with;

- $\quad$ particles are microscopic, smaller than grains of sand

- $\quad$ particles are traveling very fast, six times the speed of a bullet from a rifle, so it will tear most things

- $\quad$ Space temperature are extremely hot and extremely cold

- Space is a vacuum (absence of everything)

- Particles can not be altered when caught, (chemical composition, vaporized, crushed) want to keep original shape

- Has to survive launch into space an years of travel in space

- Needs to be lightweight to keep liftoff cost low

- Scientist have to be able to find particles

Brainstorm with your group, think of 5 possible mediums (materials) hat you could use as a particle collector. List the 5 in the chart and then complete the chart to determine which would be the best.

\begin{tabular}{|c|c|c|c|c|c|c|c|}
\hline $\begin{array}{l}\text { Collection } \\
\text { Medium }\end{array}$ & $\begin{array}{l}\text { How heavy } \\
\text { would it be? }\end{array}$ & $\begin{array}{l}\text { Will the } \\
\text { medium } \\
\text { freeze? }\end{array}$ & $\begin{array}{l}\text { Will the } \\
\text { medium melt? }\end{array}$ & $\begin{array}{l}\text { Does the } \\
\text { medium allow } \\
\text { you to see the } \\
\text { particles? }\end{array}$ & $\begin{array}{l}\text { Would the } \\
\text { medium break } \\
\text { into smaller } \\
\text { particle with } \\
\text { force? }\end{array}$ & $\begin{array}{l}\text { Would the } \\
\text { particle change } \\
\text { its shape or } \\
\text { composition } \\
\text { on contact? }\end{array}$ & $\begin{array}{l}\text { Would the } \\
\text { medium keep } \\
\text { the particle } \\
\text { perfect? }\end{array}$ \\
\hline & & & & & & & \\
\hline & & & & & & & \\
\hline & & & & & & & \\
\hline & & & & & & & \\
\hline & & & & & & & \\
\hline & & & & & & & \\
\hline
\end{tabular}

Which collection medium do you think would be the best and why? 
(This page deliberately blank) 


\section{APPENDIX C}

\section{Traditional Lesson Plans}


(this page deliberately blank) 


\section{Traditional Lesson Plans}

\section{Activity One}

The Difference Between Comets, Meteors and Asteroids

\section{Key questions:}

Do you know the difference between comets and meteors?

Did you know that comets travel across the sky very slowly?

Do you know where comets, asteroids, and meteors come from?

\section{Objectives:}

Students will be able to analyze and identify a list of characteristics pertaining to comets, meteors, and asteroids.

\section{Procedures:}

1. Students will read in Prentice Hall Science Explorer; Astronomy book pages 104107.

2. As they read the book they will answer a guided reading worksheet provided by the book publisher.

3. After students have finished the guided reading worksheet they will answer questions $1 \mathrm{abc}, 2 \mathrm{abc}$, and 3abc.

4. When complete students will hand in the class assignment.

5. Teacher will go over answers with students. 


\section{Activity Two}

\section{Famous Comet Project}

\section{Objective:}

Students will research a comet that are historically, scientifically, or otherwise significant and create a collage or poster to communicate their research findings.

\section{Procedures:}

Assign students one of the following comets;

Halley
Arend-Roland
Encke
Kohoutek
Hale Bopp
D'Arrest
Tempel-Tuttle

Swift-Tuttle

Temple1

Hyakutake

Shoemaker Levy9

Wild 2

Wilson-Harrington

Biela's Comet

2. Research the assigned comet primarily using the Internet.

3. Find the information which answers the questions below.

a. When was the comet discovered?

b. How long is this comets period?

c. Who discovered the comet and was this person a professional or amateur astronomer?

d. When did it reach its perihelion and or aphelion? (Look up words you don't know.)

e. What shape was its orbit?

f. What specific substance makes up this comet?

g. What is comets eccentricity?

h. How did this comet change the way astronomers think about comets or the Solar System? How did technology change the way we think about comets?

i. Print out a picture of the comet, label its coma, gas tail, dust tail and nucleus (if visible).

4. Create a collage or "scrap booked" Poster containing all of the required information. Answer the questions in bullet format on the poster. 


\section{Activity Three}

\section{Cometary Orbits}

Objective: Students will be able to:

- Identify the geocentric and heliocentric systems.

-Recognize how scientist such as Copernicus, Galileo, and Kepler contributed to acceptance of the heliocentric system.

-Identify the objects that make up the solar system.

\section{Procedure:}

1. Present student with notes that cover the objectives.

2. Have students read pages 72-77 in Prentice Hall Science Explore: Astronomy book.

3. Students will finish this lesson by answering question at the end of the section; questions 1 abcd, 2 abc, and 3 abc.

4. Have students hand in assignment and go over the correct answers. 
See p. 73-77 of text for information.

\section{ORBIT NOTES}

\section{HISTORY OF THEORIES}

GREEKS - noticed 5 'wanderers' in sky, called them planets

- thought Earth was center of stars \& planets=

- Ptolemy a.d. 140 - theory was but thought

planets moved in small circles within the circle of orbit

- idea lasted for years

_ other ancient Greeks thought the Sun was the center of the stars and planets $=$

- not popular theory, people didn't agree

POLISH - Nicolaus Copernicus 1543 - had right idea,

- no one believed him until Galileo ideas were made

- believed orbits of planets were perfect circles

ITALIAN - Galileo Galilei 1610 - used newly invented telescope to prove idea of the system being

DANISH - Tycho Brahe late 1500's - observed planets for 20 years, observations helped to later support Kepler's ideas.

GERMAN - Johannes Kepler (mathematician) calculated orbits and found that they did not orbit in circles, planets orbited in the shape of an which is an oval.

\section{COMETARY ORBITS}

Kepler made up 3 Laws of Planetary motion

$\# 1=$ The orbit of each planet is an with the located at the

Ellipse is a shape of an oval

- can use a string to draw one

- the tacks are $=$ foci (plural) focus (singular) 


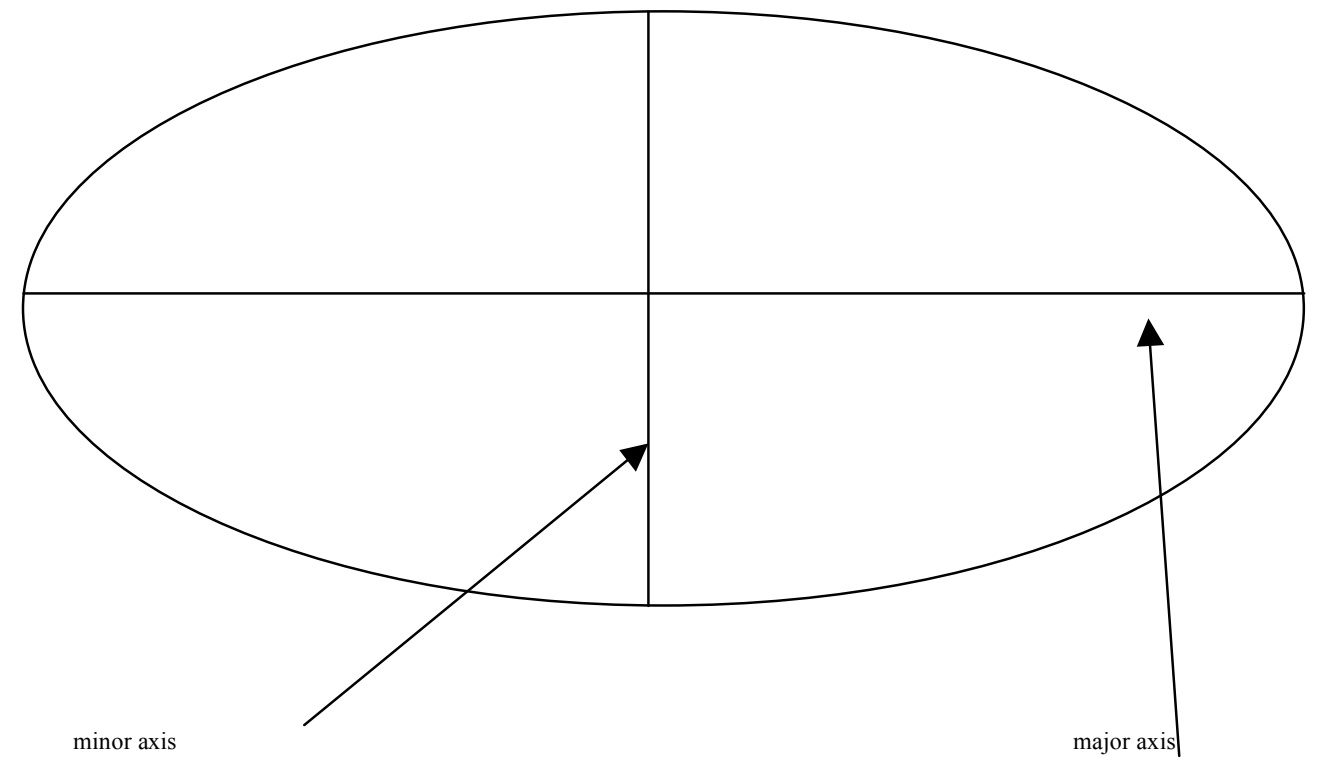

Eccentricity $=$ how stretched out the oval is

To calculate eccentricity $=$ distance between foci length of major axis

eccentricity ranges between $0-1$

closer to $0=$ more circular

closer to $1=$ more oval, long narrow

Kepler's law applies to planets but also to comets or any other orbiting object Comet orbits are more eccentric that planet orbits. 


\section{Activity Four}

\section{Investigating Falling Particles}

Objectives: Students will be able to:

-Investigate the characteristics of a clay ball.

-Examine what happens to a ball of clay that is dropped from different heights.

-Measure the height, depth, and width of a clay ball before and after a drop.

\section{Key Question}

How might an impact of a fast-moving object change the characteristics of the object?

\section{Materials and Preparation}

- Paper towels or newspapers to cover the floor

- A golf ball size clay ball

- Students data collection sheet

- Meter stick or tape measure

- Ruler

- Index cards

- Tooth pick

1. Students will observe what happens to the clay ball when it hits a hard surface at different heights.

2. Use the last ten minutes of class to have each team's reporter share the results of their experiments.

3. Students should discuss and reflect on the following questions;

a. Explain what happened to the clay ball when it was dropped.

b. How did increasing the drop height change the results of the experiment

c. What do you think would happen if you threw the clay ball at the ground at different speeds?

d. What would be the problem with a moving space craft trying to capture moving comet particles. 


\section{Appendix D}

Presurvey statements assessing the learning preference of the inquiry-based and traditionally-based curriculum students 
(this page is deliberately blank) 
Raw Data for Table 8: Pre survey statements assessing the learning preference of the

\section{inquiry-based instructed students and traditional-based instructed students}

Inquiry-based Learners' Presurvey Data

\begin{tabular}{|c|c|c|c|c|c|c|c|c|}
\hline $\begin{array}{l}\text { Stmt } \\
\text { Number }\end{array}$ & $\begin{array}{l}\text { strongly } \\
\text { disagree }\end{array}$ & disagree & Agree & $\begin{array}{l}\text { strongly } \\
\text { agree }\end{array}$ & $\begin{array}{l}\text { does not } \\
\text { apply }\end{array}$ & $N$ & Mean & SD \\
\hline 1 & 13 & 44 & 39 & 4 & 0 & 100 & 2.34 & 0.75 \\
\hline 2 & 5 & 24 & 55 & 15 & 0 & 99 & 2.81 & 0.75 \\
\hline 3 & 0 & 7 & 28 & 65 & 0 & 100 & 3.58 & 0.62 \\
\hline 4 & 10 & 38 & 42 & 10 & 0 & 100 & 2.52 & 0.81 \\
\hline 5 & 14 & 31 & 45 & 9 & 0 & 99 & 2.49 & 0.85 \\
\hline 6 & 22 & 34 & 31 & 13 & 0 & 100 & 2.35 & 0.96 \\
\hline \multirow[t]{2}{*}{7} & 2 & 31 & 48 & 16 & 0 & 97 & 2.80 & 0.73 \\
\hline & & & & & & Average $=$ & 2.70 & 0.78 \\
\hline
\end{tabular}

Traditionally-based Learners' Presurvey Data

\begin{tabular}{|c|c|c|c|c|c|c|c|c|}
\hline $\begin{array}{l}\text { Stmt } \\
\text { Number }\end{array}$ & $\begin{array}{l}\text { strongly } \\
\text { disagree }\end{array}$ & disagree & Agree & $\begin{array}{l}\text { strongly } \\
\text { agree }\end{array}$ & $\begin{array}{l}\text { does not } \\
\text { apply }\end{array}$ & $\mathrm{N}$ & Mean & SD \\
\hline 1 & 5 & 16 & 39 & 10 & 0 & 70 & 2.77 & 0.78 \\
\hline 2 & 9 & 13 & 36 & 11 & 0 & 69 & 2.71 & 0.89 \\
\hline 3 & 0 & 2 & 36 & 32 & 0 & 70 & 3.43 & 0.55 \\
\hline 4 & 9 & 31 & 27 & 3 & 0 & 70 & 2.34 & 0.75 \\
\hline 5 & 7 & 20 & 31 & 11 & 0 & 69 & 2.67 & 0.86 \\
\hline 6 & 21 & 29 & 13 & 7 & 0 & 70 & 2.09 & 0.94 \\
\hline \multirow[t]{2}{*}{7} & 4 & 18 & 38 & 8 & 0 & 68 & 2.74 & 0.74 \\
\hline & & & & & & Average $=$ & 2.68 & 0.79 \\
\hline
\end{tabular}


(this page deliberately blank) 


\section{Appendix E}

Presurvey and postsurvey statements assessing the learning preference of the inquiry-based curriculum students 
(this page deliberately blank) 


\section{Raw Data for Table 9: Presurvey and postsurvey statements assessing the learning}

preference of the inquiry-based curriculum students.

Inquiry-based Learners' Presurvey Data

\begin{tabular}{|c|c|c|c|c|c|c|c|c|}
\hline $\begin{array}{c}\text { Stmt } \\
\text { Number }\end{array}$ & $\begin{array}{l}\text { strongly } \\
\text { disagree }\end{array}$ & disagree & Agree & $\begin{array}{l}\text { Strongly } \\
\text { agree }\end{array}$ & $\begin{array}{c}\text { does not } \\
\text { apply }\end{array}$ & $\mathrm{N}$ & Mean & SD \\
\hline 1 & 13 & 44 & 39 & 4 & 0 & 100 & 2.34 & 0.75 \\
\hline 2 & 5 & 24 & 55 & 15 & 0 & 99 & 2.81 & 0.75 \\
\hline 3 & 0 & 7 & 28 & 65 & 0 & 100 & 3.58 & 0.62 \\
\hline 4 & 10 & 38 & 42 & 10 & 0 & 100 & 2.52 & 0.81 \\
\hline 5 & 14 & 31 & 45 & 9 & 0 & 99 & 2.49 & 0.85 \\
\hline 6 & 22 & 34 & 31 & 13 & 0 & 100 & 2.35 & 0.96 \\
\hline \multirow[t]{2}{*}{7} & 2 & 31 & 48 & 16 & 0 & 97 & 2.80 & 0.73 \\
\hline & & & & & & Average $=$ & 2.70 & 0.78 \\
\hline
\end{tabular}

Inquiry-based Learners' Postsurvey Data

\begin{tabular}{|c|c|c|c|c|c|c|c|c|}
\hline $\begin{array}{l}\text { Stmt } \\
\text { Number }\end{array}$ & $\begin{array}{l}\text { strongly } \\
\text { disagree }\end{array}$ & disagree & Agree & $\begin{array}{l}\text { Strongly } \\
\text { agree }\end{array}$ & $\begin{array}{l}\text { does not } \\
\text { apply }\end{array}$ & $\mathrm{N}$ & Mean & SD \\
\hline 1 & 14 & 40 & 32 & 14 & 0 & 100 & 2.46 & 0.90 \\
\hline 2 & 4 & 27 & 49 & 20 & 0 & 100 & 2.85 & 0.78 \\
\hline 3 & 2 & 5 & 27 & 66 & 0 & 100 & 3.57 & 0.68 \\
\hline 4 & 9 & 38 & 41 & 12 & 0 & 100 & 2.56 & 0.82 \\
\hline 5 & 12 & 27 & 45 & 16 & 0 & 100 & 2.65 & 0.89 \\
\hline 6 & 15 & 20 & 44 & 20 & 0 & 99 & 2.70 & 0.96 \\
\hline \multirow[t]{2}{*}{7} & 2 & 25 & 47 & 25 & 0 & 99 & 2.96 & 0.76 \\
\hline & & & & & & Average $=$ & 2.82 & 0.83 \\
\hline
\end{tabular}

Learning Preference: Pre and Post Effect Size $=0.16$ 
(this page deliberately blank 


\section{Appendix F}

Presurvey and postsurvey statements assessing the learning preference of the traditionally-based curriculum students. 
(this page deliberately blank) 
Raw Data for Table 10: Presurvey and postsurvey statements assessing the learning

preference of the traditionally-based curriculum students.

\section{Traditionally-based Learners' Presurvey Data}

\begin{tabular}{|c|c|c|c|c|c|c|c|c|}
\hline $\begin{array}{c}\text { Stmt } \\
\text { Number }\end{array}$ & $\begin{array}{l}\text { strongly } \\
\text { disagree }\end{array}$ & disagree & Agree & $\begin{array}{c}\text { strongly } \\
\text { agree }\end{array}$ & $\begin{array}{c}\text { does not } \\
\text { apply }\end{array}$ & $\mathrm{N}$ & Mean & SD \\
\hline 1 & 5 & 16 & 39 & 10 & 0 & 70 & 2.77 & 0.78 \\
\hline 2 & 9 & 13 & 36 & 11 & 0 & 69 & 2.71 & 0.89 \\
\hline 3 & 0 & 2 & 36 & 32 & 0 & 70 & 3.43 & 0.55 \\
\hline 4 & 9 & 31 & 27 & 3 & 0 & 70 & 2.34 & 0.75 \\
\hline 5 & 7 & 20 & 31 & 11 & 0 & 69 & 2.67 & 0.86 \\
\hline 6 & 21 & 29 & 13 & 7 & 0 & 70 & 2.09 & 0.94 \\
\hline \multirow[t]{2}{*}{7} & 4 & 18 & 38 & 8 & 0 & 68 & 2.74 & 0.74 \\
\hline & & & & & & Average $=$ & 2.68 & 0.79 \\
\hline
\end{tabular}

\section{Traditionally-based Learners' Postsurvey Data}

\begin{tabular}{|c|c|c|c|c|c|c|c|c|}
\hline $\begin{array}{c}\text { Stmt } \\
\text { Number }\end{array}$ & $\begin{array}{l}\text { strongly } \\
\text { disagree }\end{array}$ & disagree & Agree & $\begin{array}{l}\text { strongly } \\
\text { agree }\end{array}$ & $\begin{array}{l}\text { does not } \\
\text { apply }\end{array}$ & $\mathrm{N}$ & Mean & SD \\
\hline 1 & 5 & 27 & 28 & 10 & 0 & 70 & 2.61 & 0.82 \\
\hline 2 & 4 & 15 & 34 & 17 & 0 & 70 & 2.91 & 0.82 \\
\hline 3 & 0 & 8 & 23 & 39 & 0 & 70 & 3.44 & 0.69 \\
\hline 4 & 12 & 24 & 26 & 8 & 0 & 70 & 2.43 & 0.90 \\
\hline 5 & 5 & 29 & 21 & 13 & 0 & 68 & 2.62 & 0.87 \\
\hline 6 & 13 & 26 & 21 & 10 & 0 & 70 & 2.40 & 0.95 \\
\hline \multirow[t]{2}{*}{7} & 1 & 22 & 35 & 12 & 0 & 70 & 2.83 & 0.72 \\
\hline & & & & & & Average $=$ & 2.75 & 0.82 \\
\hline
\end{tabular}


(this page deliberately blank) 


\section{Appendix G}

Postsurvey statement assessing the learning preference of the inquiry-based instructed students and traditionally-based curriculum students. 
(this page deliberately blank) 
Raw Data for Table 11: Postsurvey statement assessing the learning preference of the

inquiry-based instructed students and traditionally-based curriculum students.

Inquiry-based Learners' Postsurvey Data

$\begin{array}{ccccccccc}\begin{array}{c}\text { Stmt } \\ \text { Number }\end{array} & \begin{array}{c}\text { strongly } \\ \text { disagree }\end{array} & \text { disagree } & \text { Agree } & \begin{array}{c}\text { strongly } \\ \text { agree }\end{array} & \begin{array}{c}\text { does not } \\ \text { apply }\end{array} & \text { N } & \text { Mean } & \text { SD } \\ 1 & 14 & 40 & 32 & 14 & 0 & 100 & 2.46 & 0.90 \\ 2 & 4 & 27 & 49 & 20 & 0 & 100 & 2.85 & 0.78 \\ 3 & 2 & 5 & 27 & 66 & 0 & 100 & 3.57 & 0.68 \\ 4 & 9 & 38 & 41 & 12 & 0 & 100 & 2.56 & 0.82 \\ 5 & 12 & 27 & 45 & 16 & 0 & 100 & 2.65 & 0.89 \\ 6 & 15 & 20 & 44 & 20 & 0 & 99 & 2.70 & 0.96 \\ 7 & 2 & 25 & 47 & 25 & 0 & 99 & 2.96 & 0.76 \\ & & & & & & & & \text { Average= }\end{array}$

Traditional-based Learners' Postsurvey Data

\begin{tabular}{|c|c|c|c|c|c|c|c|c|}
\hline $\begin{array}{l}\text { Stmt } \\
\text { Number }\end{array}$ & $\begin{array}{l}\text { strongly } \\
\text { disagree }\end{array}$ & disagree & Agree & $\begin{array}{l}\text { strongly } \\
\text { agree }\end{array}$ & $\begin{array}{l}\text { does not } \\
\text { apply }\end{array}$ & $\mathrm{N}$ & Mean & SD \\
\hline 1 & 5 & 27 & 28 & 10 & 0 & 70 & 2.61 & 0.82 \\
\hline 2 & 4 & 15 & 34 & 17 & 0 & 70 & 2.91 & 0.82 \\
\hline 3 & 0 & 8 & 23 & 39 & 0 & 70 & 3.44 & 0.69 \\
\hline 4 & 12 & 24 & 26 & 8 & 0 & 70 & 2.43 & 0.90 \\
\hline 5 & 5 & 29 & 21 & 13 & 0 & 68 & 2.62 & 0.87 \\
\hline 6 & 13 & 26 & 21 & 10 & 0 & 70 & 2.40 & 0.95 \\
\hline \multirow[t]{2}{*}{7} & 1 & 22 & 35 & 12 & 0 & 70 & 2.83 & 0.72 \\
\hline & & & & & & Average $=$ & 2.75 & 0.82 \\
\hline
\end{tabular}


(this page deliberately blank) 


\section{Appendix H}

Presurvey statements assessing the student attitude towards science of the inquiry-based and traditionally-based curriculum students. 
(this page is deliberately blank) 
Raw Data for Table 12: Presurvey statements assessing the student attitude towards

science of the inquiry-based and traditionally-based curriculum students.

\section{Inquiry-based Learners' Presurvey Data}

\begin{tabular}{|c|c|c|c|c|c|c|c|c|}
\hline $\begin{array}{c}\text { Stmt } \\
\text { Number }\end{array}$ & $\begin{array}{l}\text { strongly } \\
\text { disagree }\end{array}$ & disagree & Agree & $\begin{array}{c}\text { strongly } \\
\text { agree }\end{array}$ & $\begin{array}{c}\text { does not } \\
\text { apply }\end{array}$ & $\mathrm{N}$ & Mean & SD \\
\hline 8 & 6 & 13 & 55 & 25 & 0 & 99 & 3.00 & 0.79 \\
\hline 9 & 6 & 12 & 57 & 25 & 0 & 100 & 3.01 & 0.78 \\
\hline 10 & 26 & 34 & 27 & 13 & 0 & 100 & 2.27 & 0.99 \\
\hline 11 & 29 & 41 & 25 & 3 & 0 & 98 & 2.02 & 0.82 \\
\hline 12 & 13 & 35 & 45 & 5 & 0 & 98 & 2.43 & 0.78 \\
\hline 13 & 30 & 37 & 27 & 5 & 0 & 99 & 2.07 & 0.88 \\
\hline 14 & 21 & 38 & 31 & 10 & 0 & 100 & 2.30 & 0.91 \\
\hline 15 & 28 & 19 & 41 & 10 & 0 & 98 & 2.34 & 1.00 \\
\hline 16 & 34 & 50 & 12 & 3 & 0 & 99 & 1.84 & 0.75 \\
\hline \multirow[t]{2}{*}{17} & 15 & 13 & 17 & 53 & 0 & 98 & 3.10 & 1.13 \\
\hline & & & & & & Average $=$ & 2.44 & 0.88 \\
\hline
\end{tabular}

\section{Traditionally-based Learners' Presurvey Data}

\begin{tabular}{|c|c|c|c|c|c|c|c|c|}
\hline $\begin{array}{c}\text { Stmt } \\
\text { Number }\end{array}$ & $\begin{array}{l}\text { strongly } \\
\text { disagree }\end{array}$ & disagree & Agree & $\begin{array}{l}\text { strongly } \\
\text { agree }\end{array}$ & $\begin{array}{l}\text { does not } \\
\text { apply }\end{array}$ & $\mathrm{N}$ & Mean & SD \\
\hline 8 & 4 & 16 & 37 & 12 & 0 & 69 & 2.83 & 0.78 \\
\hline 9 & 1 & 13 & 45 & 11 & 0 & 70 & 2.94 & 0.63 \\
\hline 10 & 18 & 34 & 10 & 6 & 0 & 68 & 2.06 & 0.87 \\
\hline 11 & 18 & 27 & 17 & 6 & 0 & 68 & 2.16 & 0.92 \\
\hline 12 & 10 & 31 & 23 & 2 & 0 & 66 & 2.26 & 0.74 \\
\hline 13 & 23 & 24 & 19 & 3 & 0 & 69 & 2.03 & 0.88 \\
\hline 14 & 18 & 32 & 14 & 6 & 0 & 70 & 2.11 & 0.89 \\
\hline 15 & 15 & 28 & 20 & 7 & 0 & 70 & 2.27 & 0.91 \\
\hline 16 & 28 & 33 & 9 & 0 & 0 & 70 & 1.73 & 0.67 \\
\hline \multirow[t]{2}{*}{17} & 4 & 22 & 24 & 20 & 0 & 70 & 2.86 & 0.90 \\
\hline & & & & & & Average $=$ & 2.32 & 0.82 \\
\hline
\end{tabular}

Science Attitude: Inquiry/ Traditional Effect Size $=\mathbf{0 . 1 4}$ 
(this page deliberately blank) 


\section{Appendix I}

Pre- and postsurvey statements assessing student attitude towards science of the inquiry-based curriculum students. 
(this page deliberately blank) 
Raw Data for Table 13: Pre- and postsurvey statements assessing student attitude

towards science of the inquiry-based curriculum students.

\section{Inquiry-based Learners' Presurvey Data}

$\begin{array}{cccc}\begin{array}{c}\text { Stmt } \\ \text { Number }\end{array} & \begin{array}{c}\text { strongly } \\ \text { disagree }\end{array} & \text { disagree } & \text { Ag } \\ 8 & 6 & 13 & \\ 9 & 6 & 12 & \\ 10 & 26 & 34 & \\ 11 & 29 & 41 & \\ 12 & 13 & 35 & \\ 13 & 30 & 37 & \\ 14 & 21 & 38 & \\ 15 & 28 & 19 & \\ 16 & 34 & 50 & \\ 17 & 15 & 13 & \end{array}$

$\begin{array}{cc}\text { Agree } & \begin{array}{c}\text { strongly } \\ \text { agree }\end{array} \\ 55 & 25 \\ 57 & 25 \\ 27 & 13 \\ 25 & 3 \\ 45 & 5 \\ 27 & 5 \\ 31 & 10 \\ 41 & 10 \\ 12 & 3 \\ 17 & 53\end{array}$

\section{Inquiry based Learners' Postsurvey Data}

$\begin{array}{ccc}\begin{array}{c}\text { Stmt } \\ \text { Number }\end{array} & \begin{array}{c}\text { strongly } \\ \text { disagree }\end{array} & \text { disagree } \\ 8 & 1 & 14 \\ 9 & 3 & 16 \\ 10 & 17 & 27 \\ 11 & 29 & 34 \\ 12 & 16 & 37 \\ 13 & 30 & 39 \\ 14 & 15 & 41 \\ 15 & 23 & 21 \\ 16 & 33 & 44 \\ 17 & 14 & 14\end{array}$

Agree
$\begin{aligned} & 58 \\ & 53 \\ & 41 \\ & 28 \\ & 46 \\ & 23 \\ & 32 \\ & 35 \\ & 15 \\ & 16\end{aligned}$

strongly
agree
27
27
14
8
1
8
12
21
6
55

does not
apply
0
0
0
0
0
0
0
0
0
0

$\begin{array}{ccc}\mathrm{N} & \text { Mean } & \mathrm{SD} \\ & & \\ 99 & 3.00 & 0.79 \\ 100 & 3.01 & 0.78 \\ 100 & 2.27 & 0.99 \\ 98 & 2.02 & 0.82 \\ 98 & 2.43 & 0.78 \\ 99 & 2.07 & 0.88 \\ 100 & 2.30 & 0.91 \\ 98 & 2.34 & 1.00 \\ 99 & 1.84 & 0.75 \\ 98 & 3.10 & 1.13 \\ \text { Average }= & \mathbf{2 . 4 4} & \mathbf{0 . 8 8}\end{array}$

$\begin{array}{cccc}\begin{array}{c}\text { does not } \\ \text { apply }\end{array} & \mathrm{N} & \text { Mean } & \text { SD } \\ 0 & 100 & 3.11 & 0.66 \\ 0 & 99 & 3.05 & 0.74 \\ 0 & 99 & 2.53 & 0.94 \\ 0 & 99 & 2.15 & 0.94 \\ 0 & 100 & 2.32 & 0.75 \\ 0 & 100 & 2.09 & 0.92 \\ 0 & 100 & 2.41 & 0.88 \\ 0 & 100 & 2.54 & 1.06 \\ 0 & 98 & 1.94 & 0.85 \\ 0 & 99 & 3.13 & 1.12 \\ & \text { Average }= & \mathbf{2 . 5 3} & \mathbf{0 . 8 9}\end{array}$

Science Attitude: Pre and Post Effect Size $=0.10$ 
(this page deliberately blank) 


\section{Appendix $\mathbf{J}$}

Presurvey and postsurvey statements assessing the student attitude towards science of the traditionally-based curriculum students. 
(this page deliberately blank) 
Raw Data for Table 14: Presurvey and postsurvey statements assessing the student attitude

towards science of the traditionally-based curriculum students.

\section{Traditionally-based Learners' Presurvey Data}

\begin{tabular}{|c|c|c|c|c|c|c|c|c|}
\hline $\begin{array}{c}\text { Stmt } \\
\text { Number }\end{array}$ & $\begin{array}{l}\text { Strongly } \\
\text { disagree }\end{array}$ & disagree & Agree & $\begin{array}{c}\text { strongly } \\
\text { agree }\end{array}$ & $\begin{array}{l}\text { does not } \\
\text { apply }\end{array}$ & $\mathrm{N}$ & Mean & SD \\
\hline 8 & 4 & 16 & 37 & 12 & 0 & 69 & 2.83 & 0.78 \\
\hline 9 & 1 & 13 & 45 & 11 & 0 & 70 & 2.94 & 0.63 \\
\hline 10 & 18 & 34 & 10 & 6 & 0 & 68 & 2.06 & 0.87 \\
\hline 11 & 18 & 27 & 17 & 6 & 0 & 68 & 2.16 & 0.92 \\
\hline 12 & 10 & 31 & 23 & 2 & 0 & 66 & 2.26 & 0.74 \\
\hline 13 & 23 & 24 & 19 & 3 & 0 & 69 & 2.03 & 0.88 \\
\hline 14 & 18 & 32 & 14 & 6 & 0 & 70 & 2.11 & 0.89 \\
\hline 15 & 15 & 28 & 20 & 7 & 0 & 70 & 2.27 & 0.91 \\
\hline 16 & 28 & 33 & 9 & 0 & 0 & 70 & 1.73 & 0.67 \\
\hline \multirow[t]{2}{*}{17} & 4 & 22 & 24 & 20 & 0 & 70 & 2.86 & 0.90 \\
\hline & & & & & & Average $=$ & 2.32 & 0.82 \\
\hline
\end{tabular}

\section{Traditionally-based Learners' Postsurvey Data}

\begin{tabular}{|c|c|c|c|c|c|c|c|c|}
\hline $\begin{array}{c}\text { Stmt } \\
\text { Number }\end{array}$ & $\begin{array}{l}\text { strongly } \\
\text { disagree }\end{array}$ & disagree & Agree & $\begin{array}{c}\text { strongly } \\
\text { agree }\end{array}$ & $\begin{array}{c}\text { does not } \\
\text { apply }\end{array}$ & $\mathrm{N}$ & Mean & SD \\
\hline 8 & 3 & 20 & 30 & 17 & 0 & 70 & 2.87 & 0.83 \\
\hline 9 & 2 & 22 & 36 & 9 & 0 & 69 & 2.75 & 0.71 \\
\hline 10 & 12 & 27 & 19 & 9 & 0 & 67 & 2.37 & 0.93 \\
\hline 11 & 14 & 29 & 19 & 8 & 0 & 70 & 2.30 & 0.92 \\
\hline 12 & 8 & 29 & 22 & 8 & 0 & 67 & 2.45 & 0.85 \\
\hline 13 & 17 & 26 & 18 & 9 & 0 & 70 & 2.27 & 0.97 \\
\hline 14 & 15 & 30 & 14 & 11 & 0 & 70 & 2.30 & 0.98 \\
\hline 15 & 10 & 27 & 23 & 9 & 0 & 69 & 2.45 & 0.89 \\
\hline 16 & 21 & 33 & 11 & 4 & 0 & 69 & 1.97 & 0.83 \\
\hline \multirow[t]{2}{*}{17} & 6 & 18 & 17 & 26 & 0 & 67 & 2.94 & 1.01 \\
\hline & & & & & & Average $=$ & 2.47 & 0.89 \\
\hline
\end{tabular}


(this page deliberately blank) 


\section{Appendix K}

Postsurvey statements assessing student attitude towards science of the inquiry-based and traditionally-based curriculum students. 
(this page deliberately blank) 
Raw Data for Table 15: Postsurvey statements assessing student attitude towards science of the inquiry-based and traditionally-based curriculum students.

\section{Inquiry-based Learners' Postsurvey Data}

$\begin{array}{cr}\begin{array}{c}\text { Stmt } \\ \text { Number }\end{array} & \text { stro } \\ 8 & \text { disa } \\ 9 & 3 \\ 10 & 17 \\ 11 & 29 \\ 12 & 16 \\ 13 & 3 \\ 14 & 15 \\ 15 & 23 \\ 16 & 33 \\ 17 & 14\end{array}$

disagree

Agree

- ngree

3
17
29
16
30
15
23
33
14

strongly
agree
27
27
14
8
1
8
12
21
6
55

$\begin{array}{cccc}\begin{array}{c}\text { Stmt } \\ \text { Number }\end{array} & \begin{array}{c}\text { strongly } \\ \text { disagree }\end{array} & \text { disagree } & \text { Agree } \\ 8 & 3 & 20 & 30 \\ 9 & 2 & 22 & 36 \\ 10 & 12 & 27 & 19 \\ 11 & 14 & 29 & 19 \\ 12 & 8 & 29 & 22 \\ 13 & 17 & 26 & 18 \\ 14 & 15 & 30 & 14 \\ 15 & 10 & 27 & 23 \\ 16 & 21 & 33 & 11 \\ 17 & 6 & 18 & 17\end{array}$

\section{Traditionally-based Learners' Postsurvey Data}

17

strongly
agree
17
9
9
8
8
9
11
9
4
26

does no
apply
0
0
0
0
0
0
0
0
0
0

100

Mean SD

$3.11 \quad 0.66$

$3.05 \quad 0.74$

$2.53 \quad 0.94$

$2.15 \quad 0.94$

$2.32 \quad 0.75$

$2.09 \quad 0.92$

$2.41 \quad 0.88$

$2.54 \quad 1.06$

$1.94 \quad 0.85$

$3.13-1.12$

Average $=\quad 2.53 \quad 0.89$

does

apply
0
0
0
0
0
0
0
0
0
0

$\begin{array}{ccc}\text { N } & \text { Mean } & \text { SD } \\ 70 & 2.87 & 0.83 \\ 69 & 2.75 & 0.71 \\ 67 & 2.37 & 0.93 \\ 70 & 2.30 & 0.92 \\ 67 & 2.45 & 0.85 \\ 70 & 2.27 & 0.97 \\ 70 & 2.30 & 0.98 \\ 69 & 2.45 & 0.89 \\ 69 & 1.97 & 0.83 \\ 67 & 2.94 & 1.01 \\ \text { Average }= & 2.47 & \mathbf{0 . 8 9}\end{array}$

Science Attitude: Inquiry/ Traditional Effect Size $=\mathbf{0 . 0 7}$ 
